\title{
Nanoparticles of ZnO/Berberine complex contract COVID-19 and respiratory co-bacterial infection in addition to elimination of hydroxychloroquine toxicity
}

\author{
Doaa A. Ghareeb ${ }^{1,2,3} \cdot$ Samar R. Saleh $^{1,2,3} \cdot$ Mohamed G. Seadawy $^{4} \cdot$ Mohammed S. Nofal $^{1}$. \\ Shaymaa A. Abdulmalek ${ }^{1,2,3}$. Salma F. Hassan ${ }^{1}$. Shaimaa M. Khedr ${ }^{1}$. Miral G. AbdElwahab ${ }^{1}$. Ahmed A. Sobhy ${ }^{1,2,5}$. \\ Ali saber Ali Abdel-Hamid' · Abdelrahman Mohamed Yassin ${ }^{1}$ • Alshimaa A. Abd Elmoneam ${ }^{2,3}$. Aliaa A. Masoud ${ }^{2,3}$. \\ Mohamed M. Y. Kaddah ${ }^{1}$. Sally A. El-Zahaby ${ }^{6}$ (D) Abdulaziz Mohsen Al-mahallawi ${ }^{7,8}$. Alaa M. El-Gharbawy ${ }^{1}$. \\ Ahmed Zaki ${ }^{1}$ - Inas k. Seif ${ }^{1,2,3} \cdot$ Marwa Y. Kenawy ${ }^{2,3,9} \cdot$ Magdy Amin $^{10} \cdot$ Khaled Amer $^{11}$ - Maha Adel El Demellawy ${ }^{1,12}$
}

Received: 22 April 2021 / Accepted: 22 August 2021 / Published online: 6 September 2021

(c) The Korean Society of Pharmaceutical Sciences and Technology 2021

\begin{abstract}
Purpose A novel coronavirus (COVID-19) that has not been previously identified in humans and has no specific treatment has recently spread. Treatment trials using antiviral and immune-modulating drugs such as hydroxychloroquine (HCQ) were used to control this viral outbreak however several side effects have emerged. Berberine (BER) is an alkaloid that has been reported to reveal some pharmacological properties including antioxidant and antimicrobial activities. Additionally, Zinc oxide nanoparticles (ZnO-NPs) possess potent antioxidant and anti-inflammatory properties. Therefore, this study was undertaken to estimate the efficiency of both BER and synthetic ZnO/BER complex as an anti-COVID-19 therapy.

Methods First, the $\mathrm{ZnO} / \mathrm{BER}$ complex was prepared by the facile mixing method. Then in vitro studies on the two compounds were conducted including VeroE6 toxicity, anti-COVID-19 activity, determination of inhibitory activity towards papain-like proteinase (PL pro) and spike protein- and receptor- binding domain (RBD) as well as assessment of drug toxicity on RBCs. Results The results showed that ZnO/BER complex acts as an anti-COVID-19 by inhibiting spike protein binding with angiotensin-converting enzyme II (ACE II), PL pro activity, spike protein and E protein levels, and expression of both E-gene and RNA dependent RNA polymerase (RdRp) at a concentration lower than that of BER or ZnO-NPs alone. Furthermore, $\mathrm{ZnO} / \mathrm{BER}$ complex had antioxidant and antimicrobial properties where it prevents the auto oxidation of 2,2-Diphenyl1-picrylhydrazyl (DPPH) and the culture of lower respiratory system bacteria that affected Covid 19 patients. The $\mathrm{ZnO} / \mathrm{BER}$ complex prevented as well the HCQ cytotoxic effect on both RBC and WBC (in vitro) and hepatotoxicity, nephrotoxicity and anemia that occurred after HCQ long administration in vivo.

Conclusion The $\mathrm{ZnO} / \mathrm{BER}$ complex can be accounted as promising anti-COVID 19 candidate because it inhibited the virus entry, replication, and assembly. Furthermore, it could be used to treat a second bacterial infection that took place in hospitalized COVID 19 patients. Moreover, ZnO/BER complex was found to eliminate the toxicity of long-term administration of HCQ in vivo.
\end{abstract}

Keywords COVID-19 $\cdot$ Papain-like proteinase $\cdot$ Spike protein RBD $\cdot$ Molecular docking analysis $\cdot$ ACE2 $\cdot$ Vero E6 toxicity $\cdot$ Berberine $\cdot \mathrm{ZnO}$ nanoparticles

\section{Introduction}

Sally A. El-Zahaby

sally.elzahaby@yahoo.com

Extended author information available on the last page of the article
The outbreak of potentially lethal coronavirus disease 2019 (COVID-19), which originated from wild animals and birds, has resulted in more than 2,118,416 deaths and 98,834,415 confirmed cases until 23 January 2021 (Ghareeb et al. 2021). In fact, the outer membrane of COVID-19 virus consists of spike, envelope, and nucleocapsid that surround the viral 
RNA. Viral RNA is responsible for the expression of RNAdependent RNA polymerase (RdRp), coronavirus 3-chymotrypsin-like protease (3CLpro), and papain-like protease (PLpro) (Liu et al. 2020a).Virus invades cells through the binding of spike protein S1subunit with cell receptor; angiotensin-converting enzyme II (ACE2)and it can also bind to CD26 (Shang et al. 2020). In contrast, the spike protein $\mathrm{S} 2$ subunit is responsible for membrane fusion. The virus is entered into to host cells is via the clathr in (endosomal) and non-clathr in (non-endosomal) pathways. In both pathways, S1 binds to ACE2, then the endosomal pathway is facilitated by $\mathrm{pH}$-dependent cysteine protease catheps in $\mathrm{L}$, while non-endosomal pathway requires an additional activation/cleavage of the $\mathrm{S}$ protein into $\mathrm{S} 1$ and $\mathrm{S} 2$ domains by transmembrane protease/serine subfamily member 2 and 11D (TMPRSS2 and TMPRSS11D) (Tang et al. 2020). After virus entry, the viral single-stranded positive RNA is released and then replicated by replicase polyproteins that are processed by two cysteine proteases, 3CLpro and PLpro into 16 nonstructural proteins. The 3CLpro participates in viral replication key enzymes generation (e.g., helicase and RdRp). Beside the role of PLpro in replicase polyprotein cleavage, it suppresses type I interferon production through its deubiquitylation activity, which consequently accelerates coronaviruses-host innate immune system evasion, contributing to pathogenesis (Chen et al. 2020b; Taefehshokr et al. 2020).

Several studies have reported that about $14.3-28 \%$ of COVID-19 patients are coinfected with bacteria, fungi, and viruses like Staphylococcus aureus, Haemophilus influenzae, Streptococcus pneumoniae, Acinetobacter baumannii, Enterobacteriaceae, Aspergillus flavus, Candidaglabrata, and Candida albicans (Chen et al. 2020a; Contou et al. 2020; Langford et al. 2020; Sharifipour et al. 2020).For this reason, the usage of empiric antibiotic is encouraged.

According to WHO, the drug repurposing (Zhou et al. 2020) is the golden choice for COVID-19 treatment selections such asanti-inflammatories, immune suppressants, anti-neoplastic agents, selective estrogen receptor modulators, anti-viral drugs, and anti-malaria agents. Likewise as theone-year clinical trials, the only approved WHO drug is baricitinib (rheumatoid arthritis treatment) in combination with remdesivir (anti-viral) (WHO 2021). Moreover, it is mentioned that the inhibition of both viral cysteine proteases (PLpro and 3CLpro) function will block the viral replication and prevent the infection (Chen et al. 2020b; Taefehshokr et al. 2020).

Among many investigational or approved antiviral medications, chloroquine (CQ) and hydroxychloroquine (HCQ) are considered the most common anti-COVID-19 drugs that have been in corporated into treatment protocols. In fact, about $50 \%$ of oral dose of HCQ reaches the blood at maximum concentration $1 \mathrm{~h}$ to $2 \mathrm{~h}$ later.
Unfortunately, HCQ accumulates significantly in the liver and lung (700 times higher than plasma concentration) and then in brain and spinal cord tissue (30 times higher than plasma level). Although CQ and HCQ act as antiCOVID-19 through in vitro and in vivo studies, they have cardio-ocular toxicity (Zou et al. 2020). Basically, CQ and HCQ exert their anti-COVID-19 effect via preventing the viral entry by increasing intracellular $\mathrm{pH}$ besides interfering with the glycosylation of Severe Acute Respiratory Syndrome Coronavirus (SARS-CoV) receptors and finally inhibiting the viral replication (Liu et al. 2020b; Wang et al. 2020). According to the European Medicines Agency (2020), both CQ and HCQ can be used for the treatment without combination with other drugs or in high doses.

Berberine (BER), an is oquinoline alkaloid, has been reported to reveal some pharmacological properties including; antimicrobial activity against 54 microorganisms, intestinal ion secretion and smooth muscle contraction inhibition, hinder of ventricular tachycardia, alleviating inflammation, stimulating bile secretion and bilirubin discharge (Minaiyan et al. 2011). With regard to our previous work, we reported that BER has antioxidant, anti-inflammatory, antimicrobial, and anti-HCV properties where it acts as an NS5, RNA polymerase, indoleamine 2,3-dioxygenase (IDO), and programmed cell death protein 1 (PD1) inhibitor (Ghareeb et al. 2013; Saleh et al. 2018). Moreover, it increases INF- $\gamma$ and IL-12 production, stimulates the proliferation of dendritic cells toward T-helper1class, induces cancer cell death through increasing the expression of the apoptotic markers (Caspase- 3 and p53) associated with inflammatory markers down-regulation (myeloperoxidase, MAPK and COX-2), stimulates white blood cell proliferation, and it also has no cytotoxic effect toward normal cells in vitro and in vivo (Mahmoud et al. 2016; Ghareeb et al. 2016). Additionally, we verified the hepatoprotective effect of BER in vitro and in vivo. It effectively ameliorates the insulin signaling pathway in metabolic syndrome-induced rats by controlling glycemic and lipidemic profiles in addition to decreasing TNF- $\alpha$ and IL-6 levels (Abd El-Salam et al. 2015; Ghareeb et al. 2013, 2016, 2018; Hussien et al. 2018; Saleh et al. 2018; Soudi et al. 2019; Mahmoud et al. 2016).

Zinc oxide $(\mathrm{ZnO})$, which is a potent antioxidant and anti-inflammatory compound, has demonstrated its good antibacterial activity against Gram-positive and Gramnegative bacteria. Moreover, it has shown a promising anti-viral effect against chikungunya virus, Herpes simplex virus 1 and 2 (HSV-1 and HSV-2) and also affects the replication of influenza virus (H1N1) (Ghaffari et al. 2019). Besides that, $\mathrm{ZnO}$ is commonly used as a food additive and it was graded as a safe substance by the US Food Administration (Espitia et al. 2016; Jiang et al. 2018). 
Kim et al. (2018), proved that $\mathrm{ZnO} /$ Berberine nanoparticles could be used for lung cancer treatment due to its chemo-photothermal therapeutic efficacy.

To date, there is no research using $\mathrm{ZnO}$ nanoparticles with the complexation of berberine as antiviral agent, therefore this study is the first to consider the anti-microbial effect of $\mathrm{ZnO} /$ berberine complex. Based on these findings, the current study was conducted in order to estimate the efficiency of both BER and the well characterized synthetic $\mathrm{ZnO} / \mathrm{BER}$ complex as an anti-COVID-19 therapy, as well as to assess their possible mechanism of action. Furthermore, the current study attempts to overcome the restrictions of current therapies to examine the compounds toxicity/safety and their aptitudes to eliminate HCQ toxicity, in vitro and in vivo.

\section{Material and methods}

\section{Materials}

Berberine chloride hydrate ( $>98 \%$ purity) was purchased from Sigma Aldrich, Germany. Zinc acetate dihydrates was purchased from polskie odczynniki chemiczne S.A., Poland. Sodium hydroxide pellets were obtained from Fisher Chemical, Germany. HPLC grade ethanol and methanol were purchased from Sigma Aldrich, Germany. All other chemicals were of analytical grade.

\section{Preparation and characterization of $\mathrm{ZnO}$ nanoparticles and ZnO/BERcomplex}

\section{Preparation of $\mathrm{ZnO}$ nanoparticles}

ZnOnanoparticles ( $\mathrm{ZnO}-\mathrm{NPs}$ ) were synthesized using the solvo-thermal synthesis method, as reported in Aditya et al. (2019), with some modifications. Zinc acetate dihydrates (9.02 mmol) (Fisher Chemical, Germany) was first dissolved in $52.5 \mathrm{ml}$ of methanol/water (16:5) solution. Subsequently, $30 \mathrm{ml}$ methanol contains $17.5 \mathrm{mmol} \mathrm{NaOH}$ was drop-wisely added under vigorous stirring to the solution, followed by agitation for $30 \mathrm{~min}$ at room temperature. The pellets were collected by centrifugation for $15 \mathrm{~min}$, at 17,500 rpm. The collected pellets were washed several times by acetone: ethanol mixture. The resulting pellets were then dried overnight in a vacuum.

\section{Preparation of $\mathrm{ZnO} / \mathrm{BER}$ complex}

$\mathrm{ZnO} / \mathrm{BER}$ complex was prepared by a facile mixing method as reported in Kim et al. (2018) considering the solubility of BER and dispersibility of ZnO-NPs in different solvents. First, ZnO-NPs were dispersed in milli Q water at a concentration of $5 \mathrm{mg} / \mathrm{ml}$ using a probe-type sonicator for $30 \mathrm{~min}$.
Similarly, BER was dissolved in milli Q water at $5 \mathrm{mg} / \mathrm{ml}$ and sonicated in ultra-sonic cleaner bath for $10 \mathrm{~min}$ until complete solubility "clear bright yellow color". Then, the $\mathrm{ZnO}-\mathrm{NPs}$ suspension and BER solution were mixed and diluted with milli $\mathrm{Q}$ water while stirring. The mixture was then agitated at room temperature for $2 \mathrm{~h}$. This mixture was concentrated using a vacuum evaporator and then completely dried by using freeze dryer to obtain the complex powder. For further use and characterization, the powder was resuspended in milli Q water.

\section{Characterization methods to confirm the formation of $\mathrm{ZnO} / \mathrm{BER}$ complex}

\section{Structural and physical characterization}

\section{Zetasizer analyses}

The hydrodynamic size and polydispersity index values of $\mathrm{ZnO}-\mathrm{NPs}$ and $\mathrm{ZnO} / \mathrm{BER}$ complex were detected using dynamic light scattering (DLS) technique and Zetasizer Nano ZS (Malvern, Worcestershire, UK). In addition, zeta potential was measured using the same instrument (Raafat and El-Zahaby 2020).

\section{Transmission electron microscopy and energy dispersive X-ray analysis (EDX) analyses}

The morphology (shape and size) and elemental analysis of the $\mathrm{ZnO}-\mathrm{NPs}$ and $\mathrm{ZnO} / \mathrm{BER}$ complex were detected by transmission electron microscopy (TEM) (JEOL, JEM 1400, Tokyo, Japan) operating at an acceleration voltage of $80 \mathrm{kV}$ and energy dispersive X-ray analysis (EDX) (Oxford instruments X-Max, $80 \mathrm{~mm}^{2}$ EDS system, UK), respectively (ElZahaby et al. 2016).

\section{UV/Visible analyses}

Spectral analysis and UV/Visible absorption of BER, ZnO$\mathrm{NPs}$, and $\mathrm{ZnO} / \mathrm{BER}$ complex aqueous suspensions were detected using UV-Vis Spectrophotometer (Thermo Scientific $^{\mathrm{TM}}$ Evolution ${ }^{\mathrm{TM}}$ 300, Thermo Scientific, USA) in the range of $200-600 \mathrm{~nm}$, at room temperature with a $1 \mathrm{~cm}$ path quartz cell.

\section{Spectro fluorophotometer analyses}

The excitation and emission spectra of the BER, ZnO-NPs, and $\mathrm{ZnO} / \mathrm{BER}$ aqueous suspension were measured using a Hitachi F-2700 FL Spectro fluorophotometer, Hitachi, Japan. The fluorescence spectra were recorded at an excitation wavelength of $325 \mathrm{~nm}$ with the slits (Ex/Em) set at 
$5.0 / 10.0 \mathrm{~nm}$. Spectra were recorded in the wavelength range of $350-600 \mathrm{~nm}$ using a $1 \mathrm{~cm}$ path quartz cell.

\section{Fourier-transform infrared (FT-IR) analysis}

FTIR spectra of the BER, ZnO-NPs and $\mathrm{ZnO}$ /BER complex were obtained using a Shimadzu IRTracer-100 FT-IR spectrophotometer (Shimadzu, Japan) in a $\mathrm{KBr}$ disk. The value was detected in the wave number of $400 \mathrm{~cm}^{-1}$ to $4000 \mathrm{~cm}^{-1}$ (Wen et al. 2021).

\section{X-ray powder diffraction (XRD) analyses}

XRD experiments were performed to evaluate the change in crystalline nature of $\mathrm{ZnO}-\mathrm{NPs}$, BER and $\mathrm{ZnO} / \mathrm{BER}$ complex using Shimadzu XRD-6100 diffractometer (Shimadzu, Japan) with a copper source (1.54 $\AA$ ). Intensity (counts) values were detected in the $2 \theta$ range of $10-80^{\circ}$. The parameters of X-ray generator were determined as follows: $30 \mathrm{~mA}$ (current) and $40 \mathrm{kV}$ (tension) (Dubey et al. 2018).

\section{Quantitative and elemental analysis}

\section{HPLC and inductively coupled plasma-optical emission spectroscopy (ICP) analyses}

BER and elemental $\mathrm{Zn}$ contents in the resulting $\mathrm{ZnO} / \mathrm{BER}$ complex were quantitatively determined by using highperformance liquid chromatography (HPLC; Shimadzu HPLC LC-2010, Japan) and inductively coupled plasmaoptical emission spectroscopy (ICP-OES, PerkinElmer, UK), respectively.

\section{EDX analysis}

The elemental composition of $\mathrm{ZnO}$ and $\mathrm{ZnO}$-Ber NPs was observed by EDX technique using Oxford instruments $\mathrm{X}$-Max, $80 \mathrm{~mm}^{2}$ EDS system.

\section{In silico analysis}

First, the chemical structure of the compounds was drawn using Chem Sketch programme. This software was used to draw the structure of ligand in MOL format. Then Babel software was used to convert the format of the file from MOL file to PDB format. Protein PDB files were downloaded from www.rscb.org, then SWISS-PDBVIEWER (SPDBV) was used to co-ordinate energy minimization of the current study protein to be ready for docking. Molecular docking was performed by the software, "Auto dock 4.0and LigPlus analysis" softwarewhere the ligand (ZnO-NPs, BER and $\mathrm{ZnO} / \mathrm{BER}$ ) was docked into the protein (PLpro, spike protein and spike protein receptor-binding domain). Then Cygwin was used to create a GLG file and DLG file for running the docking algorithm and finding the minimum binding energy. Finally, UCSF Chimera software was used to visualize the docked protein and hydrogen bond analysis of the result.

\section{Anti-SARS-CoV2 assays comparing to HCQ}

\section{Determination of compounds inhibitory activity towards papain-like proteinase, spike protein-receptor binding domain and ACE2 binding (Tai et al. 2020)}

To estimate the inhibitory activity of ZnO-NPs, BER, ZnO/ BER complex or HCQ towards papain-like proteinase, spike protein-receptor binding domain and ACE2, different concentrations were used as illustrated in Table 1.

\section{Papain-like proteinase (PLpro)}

$40 \mu \mathrm{l}$ volume of $142 \mathrm{nM}$ PLpro in buffer A [50 mM HEPES, $\mathrm{pH} 7.5 ; 0.1 \mathrm{mg} / \mathrm{ml}$ bovine serum albumin (BSA), and $5 \mathrm{mM}$ Dithiothreitol (DTT)] was dispensed in 96 well plat and then incubated with $100 \mu \mathrm{l}$ of different concentrations of either BER, ZnO-NPs, or ZnO/BER complexfor 5 min. Reactions were initiated by the addition of a fluorogenic substrate,ArgLeu-Arg-Gly-Gly-AMC (Enzo Biochem, USA) (RLRGGAMC, $10 \mu \mathrm{l}$ of $250 \mu \mathrm{M}$ ) in buffer A, shaken vigorously for $30 \mathrm{~s}$, and then incubated for $6 \mathrm{~min}$. The reactions were subsequently quenched with $10 \mu \mathrm{l}$ acetic acid $(0.5 \mathrm{M})$, shaken for $30 \mathrm{~s}$, and measured for fluorescence emission intensity (excitation $\lambda: 360 \mathrm{~nm}$; emission $\lambda: 460 \mathrm{~nm}$ ). Finally, percentage of inhibition (\%) was detected.

\section{Spike protein- receptor- binding domain (RBD)}

First, SARS-CoV2, RBD (Abcam, UK) $(1 \mu \mathrm{g} / \mathrm{ml})$ was incubated with the tested compounds at $37^{\circ} \mathrm{C}$ for $2 \mathrm{~h}$. This reaction mixture was added into 96-well plate and incubated overnight at $4{ }^{\circ} \mathrm{C}$, then blocked with $2 \%$ fat-free milk in phosphate-buffered saline with Tween ${ }^{\circledR}$ detergent (PBST) for $2 \mathrm{~h}$ at $37^{\circ} \mathrm{C}$. The diluted ACE2 protein (Abcam, UK) was added to the plates and incubated for $2 \mathrm{~h}$ at $37^{\circ} \mathrm{C}$. After four washes, bound protein was detected using hACE2specific goat antibody $(0.5 \mu \mathrm{g} / \mathrm{ml}, \mathrm{R} \& \mathrm{D}$ system, USA) that was incubated for $2 \mathrm{~h}$ at $37^{\circ} \mathrm{C}$, followed by incubation of horseradish peroxidase (HRP) conjugated anti-goat IgG antibody (1:5000, Thermo Fisher Scientific, Germany) for $1 \mathrm{~h}$ at $37^{\circ} \mathrm{C}$. The reaction was visualized by the addition of the substrate, 3,3',5,5'-Tetramethylbenzidine (TMB) (Sigma, St. Louis, MO, Germany) and stopped by $\mathrm{H}_{2} \mathrm{SO}_{4}(1 \mathrm{~N})$. The 
Table 1 The inhibitory/binding effect of the tested compounds on papain like proteinase, spike protein receptor binding domine and ACE2

\begin{tabular}{lllll}
\hline Tested compounds & $\begin{array}{l}\text { Concentra- } \\
\text { tion }(\mu \mathrm{g} / \\
\mathrm{ml})\end{array}$ & PLpro (Inhibition \%) & $\begin{array}{l}\text { Spike protein- RBD- } \\
\text { complex formation (Fold } \\
\text { change) }\end{array}$ & ACE2 (Binding \%) \\
\hline ZnO-NPs & 104 & $71.06 \pm 1.30$ & $20.25 \pm 0.50$ & $16.40 \pm 0.90$ \\
& 52 & $62.20 \pm 0.90$ & $13.38 \pm 0.30$ & $15.60 \pm 0.70$ \\
& 26 & $45.60 \pm 1.10$ & $06.63 \pm 0.20$ & $13.10 \pm 1.30$ \\
& 13 & $35.31 \pm 0.77$ & $03.50 \pm 0.30$ & $10.70 \pm 0.80$ \\
BER & $22.50 \pm 0.12$ & $00.50 \pm 0.02$ & $08.20 \pm 0.08$ \\
& 6.5 & $93.26 \pm 0.73$ & $16.13 \pm 0.03$ & $15.60 \pm 1.10$ \\
& 1008 & $84.80 \pm 0.12$ & $16.13 \pm 0.20$ & $15.60 \pm 1.60$ \\
& 504 & $78.93 \pm 0.36$ & $08.50 \pm 0.00$ & $13.90 \pm 1.10$ \\
& 252 & $65.89 \pm 0.17$ & $08.00 \pm 0.10$ & $13.10 \pm 0.90$ \\
ZnO/BER & 126 & $49.80 \pm 0.19$ & $03.88 \pm 0.08$ & $13.10 \pm 0.07$ \\
& 62.5 & $98.10 \pm 0.25$ & $7.375 \pm 0.02$ & $15.60 \pm 1.01$ \\
& 166.5 & $1.625 \pm 0.05$ & $10.70 \pm 0.80$ \\
& 83.25 & $90.51 \pm 0.34$ & $1.125 \pm 0.09$ & $02.60 \pm 0.30$ \\
& 41.63 & $81.80 \pm 0.42$ & $0.75 \pm 0.008$ & $00.80 \pm 0.05$ \\
& 20.81 & $77.40 \pm 0.35$ & $0.50 \pm 0.002$ & $15.60 \pm 1.40$ \\
& 10.41 & $70.80 \pm 0.32$ & $0.50 \pm 0.001$ & $14.80 \pm 0.90$ \\
& 200 & $37.00 \pm 0.42$ & $0.50 \pm 0.001$ & $14.50 \pm 0.80$ \\
& 100 & $30.00 \pm 0.23$ & $0.38 \pm 0.003$ & $09.02 \pm 0.50$ \\
\hline & 50 & $22.50 \pm 0.15$ & $0.258 \pm 0.001$ &
\end{tabular}

The results are mean \pm SD absorbance at $450 \mathrm{~nm}$ was measured by an ELISA plate reader (Tecan, San Jose, CA) and fold change of RBD-ACE2 complex formation was estimated.

\section{ACE2 binding (confirmation test)}

In a 96-well ELISA, the diluted ACE2 protein was incubated with the tested compounds at $37^{\circ} \mathrm{C}$ for $2 \mathrm{~h}$ and then the plate was incubated overnight at $4{ }^{\circ} \mathrm{C}$. After four washes, bound protein was detected using hACE2-specific antibody (goat $0.5 \mu \mathrm{g} / \mathrm{ml}$ ) that was incubated for $2 \mathrm{~h}$ at $37{ }^{\circ} \mathrm{C}$, followed by incubation of HRP conjugated anti-goat IgG antibody (1:5000) for $1 \mathrm{~h}$ at $37^{\circ} \mathrm{C}$. The reaction was visualized by addition of TMB and stopped by $\mathrm{H}_{2} \mathrm{SO}_{4}(1 \mathrm{~N})$. The absorbance at $450 \mathrm{~nm}$ was measured by an ELISA plate reader (Tecan, San Jose, CA) and the binding \% between ACE2 and the tested compounds was detected.

\section{In vitro antiviral effect}

\section{VeroE6 toxicity}

The tested compounds were diluted with Dulbecco's Modified Eagle's Medium (DMEM). Stock solutions of the tested compounds were prepared in $10 \%$ DMSO in $\mathrm{ddH}_{2} \mathrm{O}$. The cytotoxic activity was tested in Vero E6 cells by using the 3-(4, 5-dimethylthiazol -2-yl)-2, 5-diphenyltetrazolium bromide (MTT) method with slight modification. In brief, cells were seeded into 96 -wellplates $(100 \mu \mathrm{l} /$ well at a density of $3 \times 10^{5}$ cells $/ \mathrm{ml}$ ) and incubated for $24 \mathrm{~h}$ at $37^{\circ} \mathrm{C}$ in $5 \% \mathrm{CO}_{2}$. After $24 \mathrm{~h}$, cells were treated with various concentrations of the tested compounds in triplicates and incubated for $24 \mathrm{~h}$. The supernatant was then discarded, and the cell monolayers were washed with sterile phosphate buffer saline (PBS), 3 times. MTT solution ( $20 \mu \mathrm{l} \mathrm{of} 5 \mathrm{mg} / \mathrm{ml}$ stock solution) was added to each well and incubated at $37^{\circ} \mathrm{C}$ for $4 \mathrm{~h}$ followed 
by medium aspiration. In each well, the formed formazan crystals were dissolved with $200 \mu \mathrm{l}$ of acidified isopropanol ( $0.04 \mathrm{M} \mathrm{HCl}$ in absolute isopropanol, $0.073 \mathrm{ml} \mathrm{HCl}$ in $50 \mathrm{ml}$ isopropanol). The absorbance of formazan solutions was measured at $\lambda \max 540 \mathrm{~nm}$ with $620 \mathrm{~nm}$ as the reference wavelength using a multi-well plate reader. The percentage of cyto toxicity compared to the untreated cells was determined by the following equation (Eq. 1):
(3 days). Formalin (10\%) was added for $2 \mathrm{~h}$ then plates were stained with $0.1 \%$ crystal violet in distilled water. Control wells where untreated virus was incubated with Vero E6 cells were included. Finally, the plaques were counted and the percentage reduction in plaques formation (\% Reduction) in comparison to control wells was recorded according to the following Eq. (2):

$\%$ Cytotoxicity $=\frac{(\text { absorbance of cells without treatment }- \text { absorbance of cells with treatment }) \times 100}{\text { absorbance of cells without treatment }}$

The plot of \% cytotoxicity versus sample concentration was used to calculate the concentration which exhibited $50 \%$ cytotoxicity (IC50).

\section{Anti-COVID-19 activity (Plaque reduction assay)}

In a six-well plate where Vero E6 cells $\left(1 \times 10^{6}\right.$ cells $\left./ \mathrm{ml}\right)$ were cultivated for $24 \mathrm{~h}$ at $37{ }^{\circ} \mathrm{C}$. SARS-CoV2 was diluted to give $1 \times 10^{4}$ plaque-forming unit(PFU)/well and mixed with $100 \mu \mathrm{l}$ of the safe concentration of the tested compounds and incubated for one hour at $37{ }^{\circ} \mathrm{C}$ before being added to the cells. Growth medium was removed from the cell culture plates and the cells were inoculated with $(100 \mu \mathrm{l} /$ well) of the tested compounds. After one-hour contact time for virus adsorption, $3 \mathrm{ml}$ of DMEM supplemented with $2 \%$ agarose and the tested compounds and virus was added onto the cell monolayer, plates were left to solidify, and the plates were incubated at $37{ }^{\circ} \mathrm{C}$ until the formation of viral plaques
Reduction $(\%)=\frac{\text { Viral count }(\text { untreated })-\text { Viral count }(\text { treated })}{\text { Viral count }(\text { untreated })} \times 100$

\section{Antiviral activity}

Vero E6 cells were seeded in 12-well tissue culture plates in DMEM containing 7\% fetal bovine serum (FBS), 2 mM L-glutamine, $1 \mathrm{mM}$ sodium pyruvate, $17.85 \mathrm{mM}$ sodium bicarbonate, $15 \mathrm{mM}$ HEPES and $0.8 \mathrm{mM}$ geneticin. Cells were seeds at $37{ }^{\circ} \mathrm{C}, 5 \% \mathrm{CO}_{2}$ for $24 \mathrm{~h}$ prior to infection with SARS-CoV2 at an MOI of 0.1 in infection media (according to maintenance media but containing only $2 \%$ FBS) for $2 \mathrm{~h}$. The inoculumcontaining media was removed and replaced with $1 \mathrm{ml}$ fresh media ( $2 \%$ FBS) containing different concentrations of the tested compounds (Table 2) or DMSO alone (10\%) and incubated for 3 days. The cell supernatant was collected and spun

Table 2 Effect of ZnO-NPs, BER and ZnO/BER complex on SARS-CoV2 gene expression and protein levels

\begin{tabular}{|c|c|c|c|c|c|c|c|c|c|}
\hline & $\begin{array}{l}\text { Concen- } \\
\text { tration } \\
(\mu \mathrm{g} / \mathrm{ml})\end{array}$ & $\begin{array}{l}\text { ORF gene } \\
\text { expression }\end{array}$ & $\begin{array}{l}\text { ORF gene } \\
\text { down regu- } \\
\text { lation }(\%)\end{array}$ & E-gene expression & $\begin{array}{l}\text { E-gene } \\
\text { down regu- } \\
\text { lation }(\%)\end{array}$ & RdRp expression & $\begin{array}{l}\text { RdRp down } \\
\text { regulation } \\
(\%)\end{array}$ & $\begin{array}{l}\text { E-protein } \\
\text { inhibition } \\
(\%)\end{array}$ & $\begin{array}{l}\text { Spike } \\
\text { protein } \\
\text { inhibition } \\
(\%)\end{array}$ \\
\hline \multirow[t]{4}{*}{$\mathrm{ZnO}-\mathrm{NPs}$} & 5.48 & $0.55 \pm 0.001$ & $45.29 \pm 0.9$ & \multicolumn{2}{|c|}{$0.736 \mathrm{E}^{-5} \pm 0.1 \mathrm{E}^{-6} 99.9 \pm 1.2$} & $0.001 \pm 0.0005$ & $99.89 \pm 2.8$ & $85.71 \pm 3.2$ & $83.33 \pm 4.4$ \\
\hline & 2.74 & $0.18 \pm 0.002$ & $81.96 \pm 0.3$ & \multicolumn{2}{|c|}{$0.336 \mathrm{E}^{-5} \pm 0.5 \mathrm{E}^{-6} 99.9 \pm 1.9$} & $0.018 \pm 0.0003$ & $98.20 \pm 3.1$ & $78.57 \pm 1.5$ & $78.89 \pm 3.7$ \\
\hline & 1.37 & $0.37 \pm 0.001$ & $62.63 \pm 0.7$ & \multicolumn{2}{|c|}{$5.36 \mathrm{E}^{-5} \pm 0.2 \mathrm{E}^{-6} 99.99 \pm 0.9$} & $0.019 \pm 0.0005$ & $98.10 \pm 1.5$ & $71.43 \pm 1.4$ & $66.67 \pm 2.7$ \\
\hline & 0.685 & $0.47 \pm 0.001$ & $53.35 \pm 0.2$ & \multicolumn{2}{|c|}{$7.36 \mathrm{E}^{-5} \pm 0.3 \mathrm{E}^{-6} 89.78 \pm 1.2$} & $0.0277 \pm 0.0003$ & $97.22 \pm 0.9$ & $64.29 \pm 2.4$ & $57.78 \pm 1.2$ \\
\hline \multirow[t]{4}{*}{ BER } & 20 & $0.13 \pm 0.008$ & $86.69 \pm 0.1$ & \multicolumn{2}{|c|}{$0.0002 \pm 0.0000199 .98 \pm 3.9$} & $0.001 \pm 0.00009$ & $99.89 \pm 3.8$ & $87.50 \pm 6.9$ & $96.67 \pm 1.7$ \\
\hline & 10 & $0.39 \pm 0.002$ & $60.22 \pm 0.8$ & \multicolumn{2}{|c|}{$0.003 \pm 0.000199 .70 \pm 4.5$} & $0.050 \pm 0.0003$ & $94.95 \pm 6.9$ & $50.00 \pm 4.1$ & $94.00 \pm 2.1$ \\
\hline & 5 & $0.79 \pm 0.003$ & $21.54 \pm 0.2$ & \multicolumn{2}{|c|}{$0.007 \pm 0.000599 .30 \pm 1.8$} & $0.207 \pm 0.002$ & $79.26 \pm 3.5$ & $25.00 \pm 0.9$ & $86.60 \pm 1.5$ \\
\hline & 2.5 & $0.88 \pm 0.001$ & $11.73 \pm 0.1$ & \multicolumn{2}{|c|}{$0.102 \pm 0.000389 .77 \pm 3.5$} & $0.233 \pm 0.001$ & $76.67 \pm 2.9$ & $12.50 \pm 0.8$ & $80.00 \pm 0.8$ \\
\hline \multirow[t]{4}{*}{$\mathrm{ZnO} / \mathrm{BER}$} & 1.665 & $0.12 \pm 0.001$ & $87.71 \pm 0.1$ & \multicolumn{2}{|c|}{$0.009 \pm 0.0000199 .10 \pm 1.9$} & $0.030 \pm 0.001$ & $97.00 \pm 8.4$ & $87.50 \pm 6.7$ & $93.70 \pm 5.3$ \\
\hline & 0.833 & $0.13 \pm 0.001$ & $86.82 \pm 0.5$ & \multicolumn{2}{|c|}{$0.010 \pm 0.000399 .00 \pm 0.9$} & $0.065 \pm 0.0003$ & $93.50 \pm 6.3$ & $62.50 \pm 5.4$ & $87.50 \pm 1.8$ \\
\hline & 0.416 & $0.14 \pm 0.001$ & $85.87 \pm 0.2$ & \multicolumn{2}{|c|}{$0.026 \pm 0.000297 .40 \pm 8.7$} & $0.0865 \pm 0.0002$ & $91.34 \pm 4.8$ & $37.50 \pm 3.1$ & $75.00 \pm 2.8$ \\
\hline & 0.208 & $0.27 \pm 0.001$ & $72.89 \pm 0.1$ & \multicolumn{2}{|c|}{$0.200 \pm 0.000980 .00 \pm 3.2$} & $0.1000 \pm 0.009$ & $90.00 \pm 1.7$ & $12.50 \pm 1.1$ & $62.50 \pm 3.2$ \\
\hline
\end{tabular}

The results are mean $\pm \mathrm{SD}$ 
for $10 \mathrm{~min}$ at $6000 \mathrm{rpm}$ to remove debris and the supernatant was transferred to fresh collection tubes. The cell monolayers were collected by scraping and resuspension into $1 \mathrm{ml}$ fresh media ( $2 \%$ FBS). Both supernatant and suspended cells were deactivated to kill virus particles by UV, and then several sawing and freezing steps was carried out to lysis cells (Caly et al. 2020; Xia et al. 2020).

\section{Generation of SARS-CoV2 CDNA}

RNA was extracted from $200 \mu \mathrm{l}$ aliquots of sample supernatant or cell suspension using the Qiagen viral RNA-isolation kit (\#52906). Reverse transcription was performed by the commercial first strand cDNA synthesis kit (Thermo Scientific, USA) and conducted according to the manufacturing instructions.

\section{Detection of SARS-CoV2 gene expression using a TaqMan real-time RT-PCR assay}

The amplification of BetaCoV RdRp gene and BetaCoV E-gene was carried out using the following sits of primer and probs. Regarding BetaCoV RdRp gene, $1 \mu \mathrm{M}$ Forward (5'AAA TTC TAT GGT GGT TGG CAC AAC ATG TT-3'), $1 \mu \mathrm{M}$ Reverse (5'-TAG GCA TAG CTC TRT CAC AYT T-3') primers and $0.2 \mu$ Mprobe (5'-FAM-TGG GTT GGG ATT ATC-MGBNFQ-3') (Abcam, UK) were used. With respect to BetaCoV E-gene, $1 \mu \mathrm{M}$ Forward (5'-ACA GGT ACG TTA ATA GTT AAT AGC GT -3'), $1 \mu$ M Reverse (5'-ATA TTG CAG CAG TAC GCA CAC A-3') primers and $0.2 \mu \mathrm{M}$ probe (5'-FAM-ACA CTA GCC ATC CTT ACT GCG CTT CG-286 NFQ-3') (Abcam, UK) were used. The calculated $\mathrm{Ct}$ values were converted to a fold-reduction of treated samples compared to the control using the $\Delta \mathrm{Ct}$ method (fold changed in viral $\mathrm{RNA}=2^{\wedge} \Delta \mathrm{Ct}$ ) and expressed as a percentage of the DMSO sample alone.

\section{Detection of Spike protein and envelope protein}

The protein level of spike protein and envelope protein was analyzed by ELISA technique using rabbit SARS-CoV2 spike polyclonal antibody and SARS-CoV2 envelope antibody (Abcam, UK), respectively. First, $100 \mu \mathrm{l}$ of spike and envelope proteins $(100 \mu \mathrm{g})$ were added to the well plate and incubated for $2 \mathrm{~h}$ at room temperature and then overnight at $4{ }^{\circ} \mathrm{C}$. The solution was removed then $200 \mu \mathrm{l}$ of BSA was added to the well plate and incubated for $1 \mathrm{~h}$ at $37^{\circ} \mathrm{C}$. After three-time wash with PBS, rabbit SARS-CoV2 spike or envelope polyclonal antibodies were addedto the wells and incubated for $1 \mathrm{~h}$ at room temperature. After threetime wash with PBS,HRP conjugated anti-rabbit IgG antibody was added to the wells and incubated for $1 \mathrm{~h}$ at room temperature. The reaction was visualized by the addition of a chromogenic substrate (TMB)and stopped by $\mathrm{H}_{2} \mathrm{SO}_{4}(1 \mathrm{~N})$. The absorbance was measured at $450 \mathrm{~nm}$ by an ELISA plate reader (Tecan, San Jose, CA).

\section{In vitro assays of biological activities of the tested compounds compared to HCQ}

\section{Red blood cells toxicity}

First, a serial dilution of BER, ZnO-NPs, ZnO/BER complex and $\mathrm{HCQ}$ was prepared in $0.9 \% \mathrm{NaCl}$ ranging from $2 \mu \mathrm{g} / \mathrm{ml}$ to $1000 \mu \mathrm{g} / \mathrm{ml}$. Then, $100 \mu \mathrm{l}$ of $1 \%$ human red blood cells suspension was added to a new microtube containing $900 \mu \mathrm{l}$ dilutions of each compound tested andincubated at $37^{\circ} \mathrm{C}$ for $1 \mathrm{~h}$. After that, the tubes were centrifuged at $3000 \times g$ for $5 \mathrm{~min}$. The supernatant $(200 \mu \mathrm{l})$ was placed in a 96-well plate and the absorbance was measured at $540 \mathrm{~nm}$ using a microplate reader. "For positive(100\% haemolysis) and negative( $0 \%$ haemolysis)controls", the cells suspension of human red blood cells $(100 \mu \mathrm{l})$ were mixed with distilled water or $0.9 \% \mathrm{NaCl}(900 \mu \mathrm{l})$, respectively. The percentage of haemolysis was calculated as the following Eq. (3):

Hemolysis $(\%)=\frac{\left(A b s_{\text {sample }}-A b s_{C-}\right)}{\left(A b s_{C+}-A b s_{C-}\right)} \times 100$

where, $A b s_{\text {sample }}$ was the absorbance of different tested compounds, $A b s_{C+}$ was the absorbance of positive control (100\% hemolysis) and $A b s_{C-}$ was the absorbance of negative control (0\% haemolysis).All samples were assayed in triplicates. Finally, the inhibitory or effective concentration (IC50/ EC50) which had 50\% anti-hemolytic powerful and caused $50 \%$ red blood cells hemolysis was estimated in $\mu \mathrm{g} / \mathrm{ml}$.

\section{Peripheral blood mononuclear cells toxicity}

Peripheral blood mononuclear cells (PBMC) were collected from healthy individuals on heparinized tubes (10 $\mathrm{U} / \mathrm{ml}$ ) and PBMC were collected by density gradient centrifugation using sterile lymphocyte separation medium (Ficoll-Paque premium, density $1.077 \mathrm{~g} / \mathrm{ml}$, GE Healthcare, USA). Cell count and viability were determined using trypan blue exclusion test. Finally, the separated PBMC was suspended at $1.0 \times 10^{5} \mathrm{cell} / \mathrm{ml}$ in Roswell Park Memorial Institute (RPMI) 1640 medium (Lonza, USA) supplemented with $25 \mathrm{mM} \mathrm{N}$-2-hydroxyethylpiperazine$\mathrm{N}^{`}$-2-ethanesulfonic acid (Lonza), $4 \mathrm{mM} \mathrm{L}$-glutamine (Lonza), $100 \mathrm{U}$ of penicillin and $100 \mu \mathrm{g}$ streptomycin (Cambrex) and 10\% FBS (Lonza). PBMC was incubated with different concentrations of the tested compounds. 
All samples were assayed in triplicates. Proliferation was assessed using a neutral red uptake assay (Repetto et al. 2008) after incubation for $24 \mathrm{~h}$ at $37{ }^{\circ} \mathrm{C}, 5 \% \mathrm{CO}_{2}$, and $95 \%$ humidity. Finally, IC50 was calculated in $\mu \mathrm{g} / \mathrm{ml}$.

\section{Antioxidant activity}

The free radical scavenging activity of the tested compounds was measured by 2,2-Diphenyl-1-picrylhydrazyl (DPPH, Sigma, Germany) assay as proposed by BrandWilliams et al. (1995), with some modifications. A solution of $0.2 \mathrm{mM}$ DPPH in methanol $(0.0078 \mathrm{~g} / 100 \mathrm{ml})$ was prepared and $100 \mu \mathrm{l}$ of this radical solution was added to $100 \mu \mathrm{l}$ of the tested compounds at different concentrations. The mixture was incubated in the dark for $30 \mathrm{~min}$ at room temperature. For control (no radical scavenging activity), $100 \mu \mathrm{l}$ of distilled water was used instead of the tested compounds. Then the absorbance of samples $\left(A b s_{\text {Sample }}\right)$ and control ( $\left.A b s_{\text {control }}\right)$ was measured at $517 \mathrm{~nm}$ using a microplate reader. The percentage of DPPH radical-scavenging activity was calculated using the following equation, Eq. (4): the well diameter. The readings were taken in three different fixed directions in all triplicates and the average values were tabulated.

\section{Turbidity assay}

MIC of samples was performed using the microdilution method. Briefly, cultures of bacteria broth were suspended overnight in Mueller Hinton (MH) broth with turbidity adjusted to $0.5 \mathrm{McF}$ arland, resulting in a suspension containing approximately $1 \times 10^{8} \mathrm{CFU} / \mathrm{ml}$. To measure the MIC, $50 \mu \mathrm{l}$ of MH broth culture was poured into 12 wells of a 96-wellmicrotiter plate. In the first well, $50 \mu \mathrm{l}$ of the samples stock solution was added. A twofold dilution was then made to obtain a different concentration of samples in each well $(\mu \mathrm{g} / \mathrm{ml})$. Then50 $\mu \mathrm{l}$ of the microbial suspension was added to each well. The microplate was then incubated at $37^{\circ} \mathrm{C}$ for $24 \mathrm{~h}$, and the sample concentration in the well without visible growth of the bacterial cells was considered to be MIC. The positive control (maximum bacterial growth) contained MH broth medium only with tested bacterial concentration and a negative control contained only inoculated broth were used in the study. The test was carried out in comparison

DPPH radical scavenging activity (\% Inhibition) $=\frac{\left(A b s_{\text {Control }}-A b s_{\text {Sample }}\right)}{A b s_{\text {Control }}} \times 100$

\section{Antimicrobial activity}

Antimicrobial activity was performed by using agar well diffusion assay and turbidity assay (Kadaikunnan et al. 2015) for all samples. Four microbial species known to be pathogenic including gram negative bacteria (klebsila pneumonia ATCC700603), gram positive bacteria(Staphylococcus aureus ATCC25923 and Streptococcus pyogenes EMCC1772) and yeast (Candida albicansEMCC105) were tested. Strains were grown in nutrient broth at $37^{\circ} \mathrm{C}$ for $24 \mathrm{~h}$. A set of 5 concentrations of the tested reconstituted compounds were examined to determine the minimum inhibitory concentration (MIC) of each against a specific pathogenic strain.

\section{Agar well diffusion assay}

One hundred microliters of inoculums $\left(1 \times 10^{8} \mathrm{CFU} / \mathrm{ml}\right)$ were inculcated on agar media and poured into the petri plate. A well was prepared in the plates with the help of a cork-borer $(0.5 \mathrm{~cm})$ and $100 \mu \mathrm{l}$ of the tested compounds were applied into the well. All tested bacterial were incubated at $37{ }^{\circ} \mathrm{C}$ for $24 \mathrm{~h}$. The inhibition zone was calculated by measuring the diameter around the well $(\mathrm{mm})$, excluding with $10 \mathrm{mg} / \mathrm{ml}$ amoxicillin. The optical density was measured at $600 \mathrm{~nm}$. MIC was defined as the least concentration of the sample that visually inhibited the bacterial growth after $24 \mathrm{~h}$ of incubation. MIC was reported by observing the visual turbidity of the tubes before and after incubation. Bacteria inhibition (\%) was calculated as the following Eq. (5):

Inhibition $(\%)=\frac{\left(A b s_{\text {Control }}-A b s_{\text {Sample }}\right)}{A b s_{\text {Control }}} \times 100$

\section{The elimination of HCQ toxicity}

\section{In vitro assay}

\section{Red blood cells toxicity}

One hundred microl liters of $1 \%$ red blood cells suspension was added to $450 \mu \mathrm{l}$ of dilution of each tested compound that gave the lowest haemolytic activity and incubated at $37{ }^{\circ} \mathrm{C}$ for $30 \mathrm{~min}$. After that, $450 \mu \mathrm{l}$ of HCQ $(27.5 \mu \mathrm{g} / \mathrm{ml})$ was added to all of test compounds and re-incubated for another $30 \mathrm{~min}$. After that, the supernatant $(200 \mu \mathrm{l})$ was placed in a 
96-well plate and the absorbance was measured at $540 \mathrm{~nm}$ using a microplate reader. Finally, the percentage of haemolysis was calculated as previously mentioned in 2.5.1.

\section{White blood cells toxicity}

The blood sample $(10 \mathrm{ml})$ was centrifuged at $1650 \mathrm{rpm}$ for $10 \mathrm{~min}$ and pellets were collected. Then lysis buffer (10 times of pellet volume) was added to the pellet and centrifuged for $30 \mathrm{~min}$ at $1650 \mathrm{rpm}$. The supernatant was discarded, and the white pellet was resuspended in one $\mathrm{ml}$ RPMI 1640 medium (Lonza, USA). Cell count and viability were determined using trypan blue exclusion test. Finally, the separated WBCs were suspended at $1 \times 10^{5} \mathrm{cell} / \mathrm{ml}$ in RPMI 1640 medium supplemented with $25 \mathrm{mM} \mathrm{N}$-2-hydroxyethylpiperazine-N`-2-ethanesulfonic acid (Lonza), $4 \mathrm{mM} \mathrm{L}$-glutamine (Lonza), $100 \mathrm{U}$ of penicillin and $100 \mu \mathrm{g}$ streptomycin (Cambrex) and 10\% FBS (Lonza). Cells $(100 \mu \mathrm{l})$ were incubated with $100 \mu \mathrm{l}$ of different concentrations of the tested compounds for $24 \mathrm{~h}$ at $37^{\circ} \mathrm{C}, 5 \% \mathrm{CO}_{2}$, and 95\% humidity. After that, media were changed with media contained $200 \mu \mathrm{g} / \mathrm{ml}$ HCQ and the cells was incubated for another $24 \mathrm{~h}$. All samples were assayed in triplicates. Proliferation was assessed using neutral red uptake assay (Repetto et al. 2008).

\section{In vivo assay}

Thirty-six male albino mice weighing $20-25 \mathrm{~g}$ were purchased from the Theodor Bilharz Research Institute, Cairo, Egypt. Mice were housed in an animal facility of Pharmaceutical and Fermentation Industries Development Centre (PFIDC), SRTA-City. Animals were housed 6 mice/cages under controlled temperature $\left(25 \pm 2{ }^{\circ} \mathrm{C}\right)$ and constant photoperiodic conditions (12:12-h daylight/darkness). Mice were allowed free access to water and a balanced commercial chow. The animal experiment design protocol was approved by ethics committee of animal research in (PFIDC), SRTACity, Institutional Animal Care and Use Committees (IACUC)/IACUC \# 19-1R-01020.

The animals were divided into six groups. The first 3 groups received orally $250 \mu$ lof either milliQ water (control), BER solution (100 mg/kg, BER group) and $\mathrm{ZnO} /$ BER solution (3.3 mg/kg, ZnO/BER group).The second 3 groups received the previous treatments in combination with $250 \mu \mathrm{l}$ of HCQ solution ( $36 \mathrm{mg} / \mathrm{kg}$ ) and named after the HCQ,HCQ+BERand HCQ + ZnO/BER groups, respectively. All the treatments are dissolved in milliQ water and continued for 28 days.

At the end of the experimental period, mice were fasted overnight, and then anesthetized with sodium pentobarbital (100 mg/kg i.p.) to minimize animal suffering. Blood samples were collected in heparinized test tubes. After complete blood picture (CBC) determination, plasma was isolated by centrifugation and sera were collected to measure routine blood chemistry.

CBC was analyzed using an automated hematology analyzer (BC-2800Vet-Mindray, China) as well as blood parameters (alanine aminotransferase (ALT), aspartate aminotransferase (AST) and alkaline phosphatase (ALP) activities as well as total protein, albumin, bilirubin, triglyceride (TG),creatinine, uric acid and urea levels) were measured using a clinical chemistry analyzer (BS-230-Mindray, China) according to commercial kit manufacturing instructions.

\section{Statistical analysis}

SPSS software package version 20.0(Armonk, NY: IBM Corp) was used for data analyses. Data are presented as mean and standard deviation, significance among groups at $p<0.05$ was assessed by using ANOVA and post hoc LSD test.

\section{Results and discussion}

\section{Characterization of $\mathrm{ZnO}$ nanoparticles and $\mathrm{ZnO/BER}$ complex}

UV-vis spectral analysis (Fig. 1a) shows that the characteristic absorption peak for wurzite hexagonal ZnO-NPs was found at $372 \mathrm{~nm}$ (Estrada-Urbina et al. 2018). While the absorbance at 228, 260, 344 and $420 \mathrm{~nm}$ is the characteristic absorption peaks for berberine chloride. In $\mathrm{ZnO} / \mathrm{BER}$ complex spectrum, the characteristic absorption peaks were like BER alone. Moreover, the ZnO-NPs specific absorption peak was hidden and there was a slight broadening and increase in the absorbance intensity peak at $420 \mathrm{~nm}$ of BER in $\mathrm{ZnO} / \mathrm{BER}$ complex spectrum (Fig. $1 \mathrm{~b}$ and c). These effects are may be due to the absorption of BER on the surface of $\mathrm{ZnO}-\mathrm{NPs}$ and the formation of ground state complex formed by $\mathrm{ZnO} / \mathrm{BER}$ complex interaction (Bhogale et al. 2013) and formation of $\mathrm{ZnO} / \mathrm{BER}$ complex aggregates.

The fluorescence intensities of BER aqueous solution in the range of 350-600 nm which presented in Fig. 1d shows a pair of very low fluorescence intensity at $\lambda_{\max }=370 \mathrm{~nm}$ and $\lambda_{\max }=540 \mathrm{~nm}$ respectively. The fluorescence spectrum of the $\mathrm{ZnO}$-NPs aqueous suspension exhibits most of the ZnO-NPs characteristic emission peaks at $378 \mathrm{~nm}, 455 \mathrm{~nm}$, and $534 \mathrm{~nm}$ (Irimpan et al. 2007). The fluorescence intensities of the $\mathrm{ZnO} / \mathrm{BER}$ complex shows the quenching of the $\mathrm{ZnO}$ band emission peaks at $\lambda_{\max }=378 \mathrm{~nm}$ by $48.32 \%$ with $2 \mathrm{~nm}$ shifting to $\lambda_{\max }=380 \mathrm{~nm}$. Moreover, the fluorescence intensity peaks at $455 \mathrm{~nm}$ and $534 \mathrm{~nm}$ still has the same intensity with shifting 11 and $1 \mathrm{~nm}$, respectively. However, 
(a)

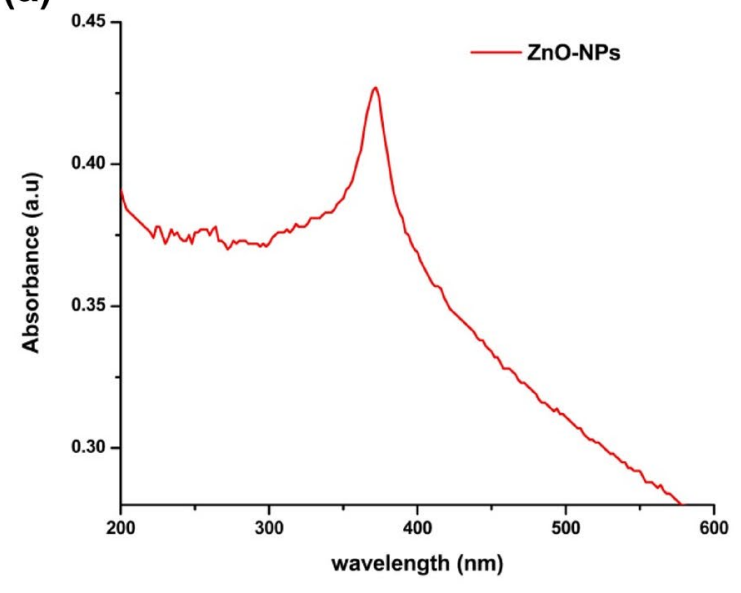

(c)

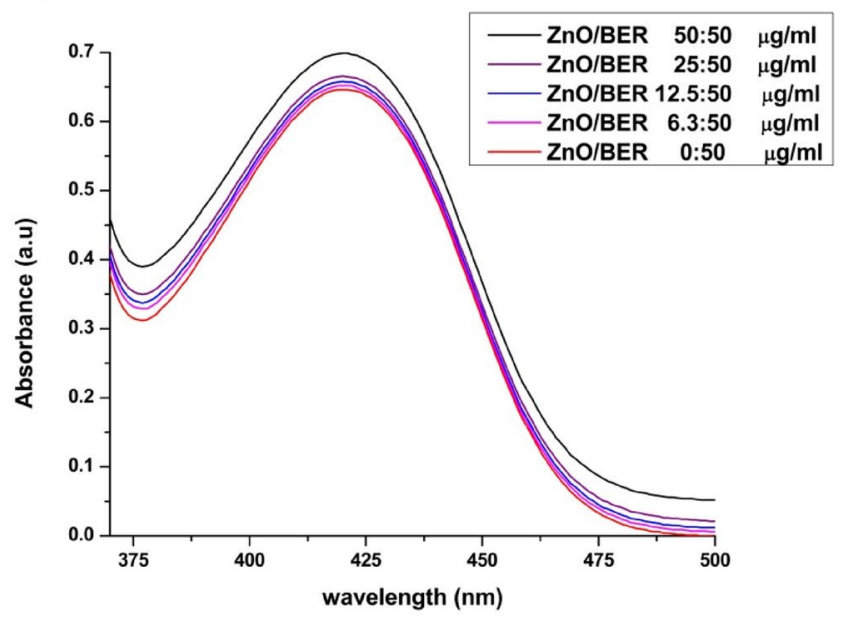

(b)

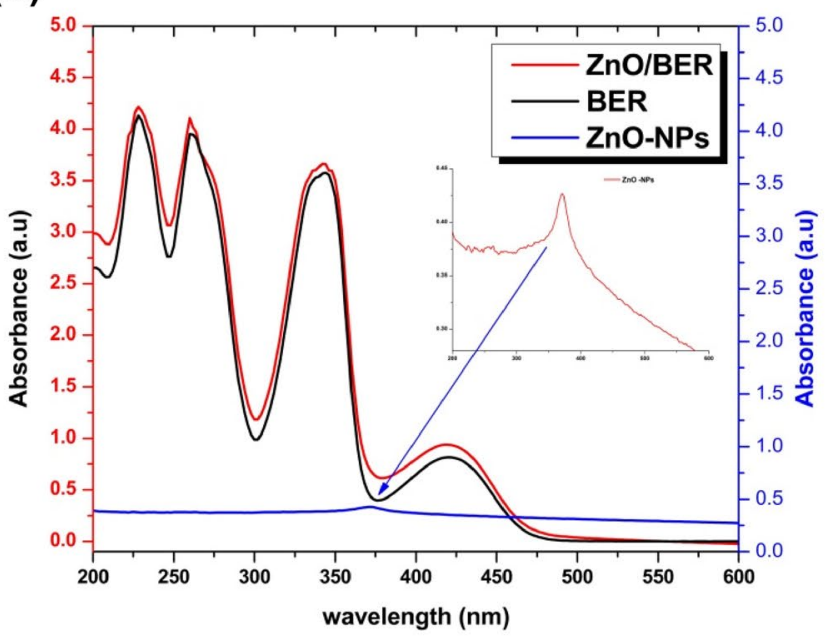

(d)

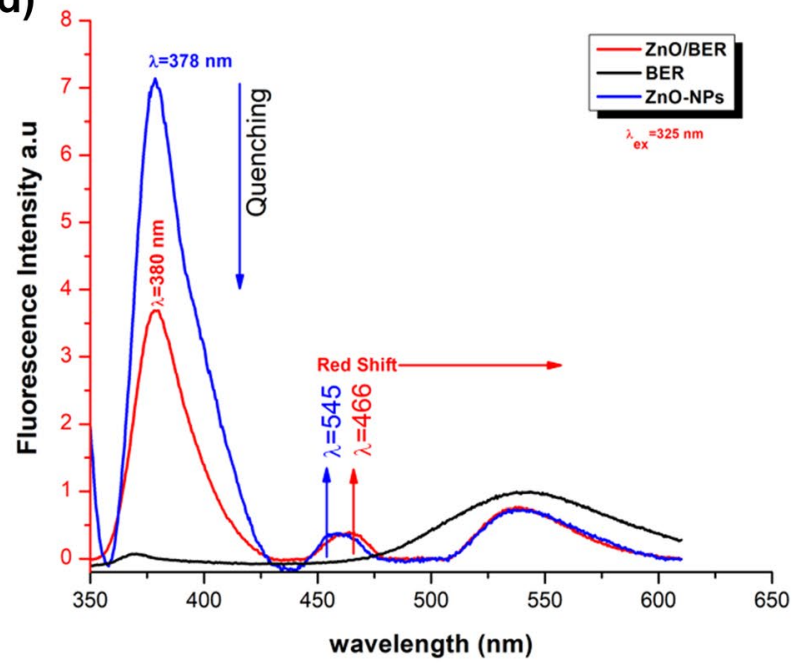

(e)

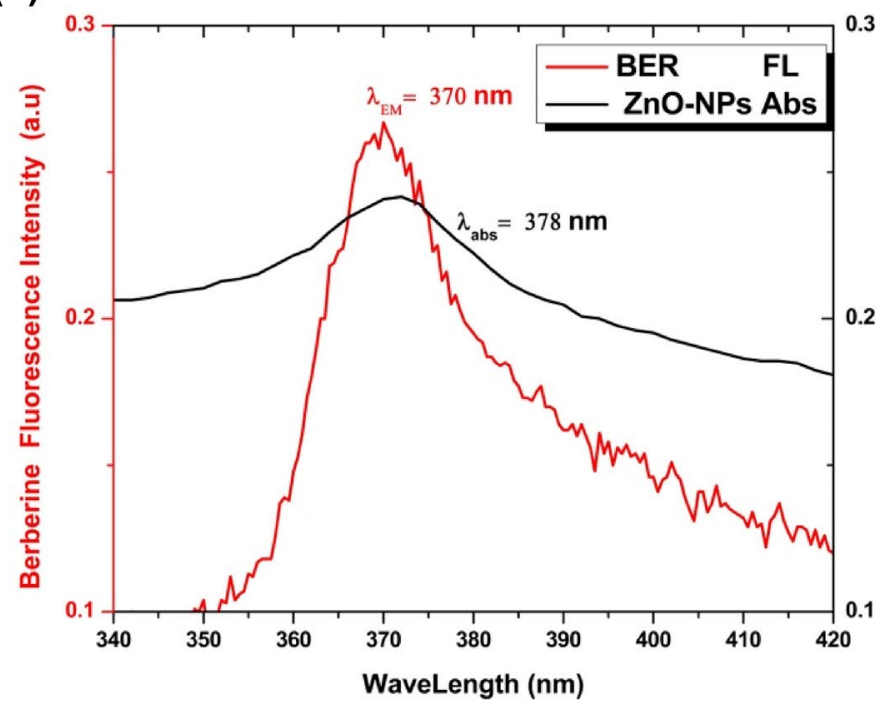


4Fig. 1 Absorption spectrum of a ZnO-NPs suspension $(104 \mu \mathrm{g} / \mathrm{ml})$, b BER $(62.5 \mu \mathrm{g} / \mathrm{ml}$, Black $)$ and ZnO/BER-NPs $(166.5 \mu \mathrm{g} / \mathrm{ml}$, Red $)$ and $\mathrm{ZnO}-\mathrm{NPs}(104 \mu \mathrm{ug} / \mathrm{ml}$, Blue $)$ and $\mathbf{c}$ BER and $\mathrm{ZnO} / \mathrm{BER}$ peaks at $420 \mathrm{~nm}$ with different $\mathrm{ZnO}-\mathrm{NPs}$ concentration. $\mathbf{d}$ The fluorescence emission spectrum at $\lambda$ excitation $=325 \mathrm{~nm}$ of the prepared materials suspended in milli $\mathrm{Q}$ water at room Temperature. BER $(62.5 \mu \mathrm{g} /$ $\mathrm{ml}, \mathrm{pH}=7.5$, Black $)$ and $\mathrm{ZnO} / \mathrm{BER}(166.5 \mu \mathrm{g} / \mathrm{ml}, \mathrm{PH}=7.21$, Red $)$ and $\mathrm{ZnO}-\mathrm{NPs}(104 \mu \mathrm{ug} / \mathrm{ml}, \mathrm{pH}=7.45$, Blue $)$. e Overlap of the fluorescence emission spectrum of BER with the absorption spectrum of $\mathrm{ZnO}-\mathrm{NPs}$

in the presence of colloidal $\mathrm{ZnO}-\mathrm{NPs}$, the emission peaks of the BER band around $370 \mathrm{~nm}$ and $540 \mathrm{~nm}$ were hidden in $\mathrm{ZnO}$-BER spectrum. This generally occurs due to passivation of $\mathrm{ZnO}-\mathrm{NPs}$ surface and the energy transfer interaction that appears in the overlap of the emission spectrum of the donor with absorption spectrum of the acceptor (Belay et al. 2017; Jia et al. 2014; Kathiravan et al. 2009). Figure 1e clearly shows that fluorescence emission spectrum of BER overlapped with the absorption spectrum of ZnO-NPs, indicating energy transfer from the excited state of BER to $\mathrm{ZnO}-\mathrm{NPs}$ resulting in the formation of $\mathrm{ZnO} / \mathrm{BER}$ complex at lower energy.

Figure 2 shows that the average hydrodynamic size of $\mathrm{ZnO}-\mathrm{NPs}$ was approximately $448 \mathrm{~nm}$ due to their tendency to aggregate in aqueous suspension, whereas the average hydrodynamic size of $\mathrm{ZnO} / \mathrm{BER}$ complex was approximately $583 \mathrm{~nm}$. The polydispersity index (PDI) and zeta potential of $\mathrm{ZnO}-\mathrm{NPs}$ was $0.255 \mathrm{mv}$ and $-25.5 \mathrm{mv}$, respectively while the $\mathrm{ZnO} / \mathrm{BER}$ complex was $0.32 \mathrm{mv}$ and $-3.71 \mathrm{mv}$, respectively. This result is due to the interaction between the negative $\mathrm{ZnO}-\mathrm{NPs}$ and the cationic BER molecules which affects the polydispersity index and increases the tendency to aggregate due to the low surface potential of the complex (Liu et al. 2018).

Figure $3 \mathrm{a}$ shows that ZnO-NPs are highly uniformly dispersed NPs with a particle size of $30 \pm 5 \mathrm{~nm}$ with the presence of some larger agglomerated particles. Moreover, the EDX elemental analysis of ZnO-NPs (Fig. 3c) showed that $\mathrm{Zn}$ and $\mathrm{O}$ are the main constituents in the sample and there were no traces of another element. TEM analysis of the $\mathrm{ZnO} / \mathrm{BER}$ complex (Fig. 3b) showed that there were $\mathrm{ZnO}-\mathrm{NPs}$ agglomerated clusters shield with a light organic layer of BER with a particle size of $65 \pm 6 \mathrm{~nm}$. The size was increased as the aggregates of the $\mathrm{ZnO} / \mathrm{BER}$ complex were formed and this may explain the increased hydrodynamic size and the PDI of ZnO/BER complex sample. Furthermore, the EDX elemental analysis of the ZnO/BER complex (Fig. 3d) shows the presences of C, Zn and O only. Additionally, Fig. $3 \mathrm{c}$ shows that the content of BER in $\mathrm{ZnO} / \mathrm{BER}$ complex was $(67.068 \pm 2.43 \mu \mathrm{g} / \mathrm{ml})$, while the $\mathrm{Zn}$ content was $79.55 \mu \mathrm{g} / \mathrm{ml}$.

To verify the intermolecular interactions between BER and $\mathrm{ZnO}-\mathrm{NPs}$ in the $\mathrm{ZnO} / \mathrm{BER}$ complex, infrared absorption spectra of $\mathrm{ZnO}-\mathrm{NPs}$, BER, and $\mathrm{ZnO} / \mathrm{BER}$ complex were observed in the wavenumber range from $4000 \mathrm{~cm}^{-1}$ to $-400 \mathrm{~cm}^{-1}$ (Fig. 4a). The FT-IR of ZnO-NPs and BER was identical to the data published by Nagaraju et al. (2017) for ZnO-NPs and Bashmakova et al. (2011), Battu et al. (2010), Strekal et al. (2007)for BER. The FT-IR spectrum of the $\mathrm{ZnO} / \mathrm{BER}$ complex shows a significant vibration band in the range of $400-500 \mathrm{~cm}^{-1}$ which is a characteristic stretching mode of the $\mathrm{Zn}-\mathrm{O}$ divalent bond at $427 \mathrm{~cm}^{-1}$ and surface hydroxyl residue $-\mathrm{O}-\mathrm{H}$ stretching mode in the range of $3000-3600 \mathrm{~cm}^{-1}$ (at $3405 \mathrm{~cm}^{-1}$ ). The $\mathrm{CH}_{2}-\mathrm{O}-\mathrm{CH}_{2}$, the BER ether group vibration peak $\left(923 \mathrm{~cm}^{-1}\right.$ and $\left.1032 \mathrm{~cm}^{-1}\right)$ (Bashmakova et al. 2011) appeared with lower absorption intensity with a red shift at 903 and $1034 \mathrm{~cm}^{-1}$. While the BER-OCH $\mathrm{OCH}_{3}$ methoxy group rocking and stretching vibration peak at $1270 \mathrm{~cm}^{-1}$ and $1390 \mathrm{~cm}^{-1}$ (Strekal et al. 2007) with lower absorption intensity at $1270 \mathrm{~cm}^{-1}$ peak and enhanced absorption intensity at $1390 \mathrm{~cm}^{-1}$ peak. This may be due to the overlapping with $-\mathrm{OCH}_{3}$ methoxy group over the surface of $\mathrm{ZnO}$ from the synthesis precursors. Also, The BER iminium $\left(\mathrm{C}=\mathrm{N}^{+}\right)$double bond peak at $1627 \mathrm{~cm}^{-1}$ (Battu et al. 2010) experiences a dramatic change. It disappeared in the $\mathrm{ZnO} / \mathrm{BER}$ complex spectrum, and the $-\mathrm{C}-\mathrm{N}$ vibration peak of BER at $1141 \mathrm{~cm}^{-1}$ and $1567 \mathrm{~cm}^{-1}$ could not be noticed. Moreover, the existence of aromatic ring stretching vibrations of $\mathrm{C}-\mathrm{C}, \mathrm{C}=\mathrm{C}$ at $1331 \mathrm{~cm}^{-1}, 1558 \mathrm{~cm}^{-1}$, $1506 \mathrm{~cm}^{-1}$ and $1600 \mathrm{~cm}^{-1}$. The FT-IR spectrum of the BER and $\mathrm{ZnO} / \mathrm{BER}$ complex showed that the BER-OCH $\mathrm{OH}_{3}$ methoxy group, $-\mathrm{C}-\mathrm{N}$, iminium $\left(\mathrm{C}=\mathrm{N}^{+}\right)$double bond peak and $\mathrm{CH}_{2}-\mathrm{O}-\mathrm{CH}_{2}$ ether pair peaks experienced a dramatic change in shape, transmittance (\%) and band position. It implies the interactions between the principal functional groups of BER and $\mathrm{ZnO}$ in the $\mathrm{ZnO} / \mathrm{BER}$ complex.

The structure type identification and crystallinity of $\mathrm{ZnO}$ NPs, BER and ZnO/BER complex showed that the XRD pattern (Fig. 4b) of prepared $\mathrm{ZnO}$-NPs has sharp and intense diffraction peaks at $2 \theta$ of $31.516^{\circ}, 34.168^{\circ}$ and $36.002^{\circ}$ correspond to $100,002,101$ planes where these are characteristic peaks of polycrystalline hexagonal wurzite $\mathrm{ZnO}$. Furthermore, The XRD pattern of BER shows sharp and intense diffraction peaks at $2 \theta$ of $8.8452^{\circ}, 26.0359^{\circ}$ and $25.1644^{\circ}$, which indicates the crystalline nature of BER. The XRD pattern of the prepared $\mathrm{ZnO} / \mathrm{BER}$ complex shows sharp and intense diffraction peaks for $\mathrm{ZnO}-\mathrm{NPs}$ at $2 \theta$ of $31.6647^{\circ}$, $34.3182^{\circ}$ and $36.1569^{\circ}$, in addition to the presence of less intense diffraction peaks of BER indicating the presence of less crystalline (semi-crystalline) form of BER on the surface of $\mathrm{ZnO}-\mathrm{NPs}$. The average size of the nanoparticles is calculated using Debye-Scherrer equation; $\mathrm{D}=0.9 \lambda / \operatorname{Cos} \theta$ equation, which was estimated of $30 \pm 5 \mathrm{~nm}$.

The proposed structure of the formulated $\mathrm{ZnO} / \mathrm{BER}$ complex is illustrated in (Fig. 4c). The electrostatic interaction between the negatively charged $\mathrm{ZnO}-\mathrm{NPs}$ and the 

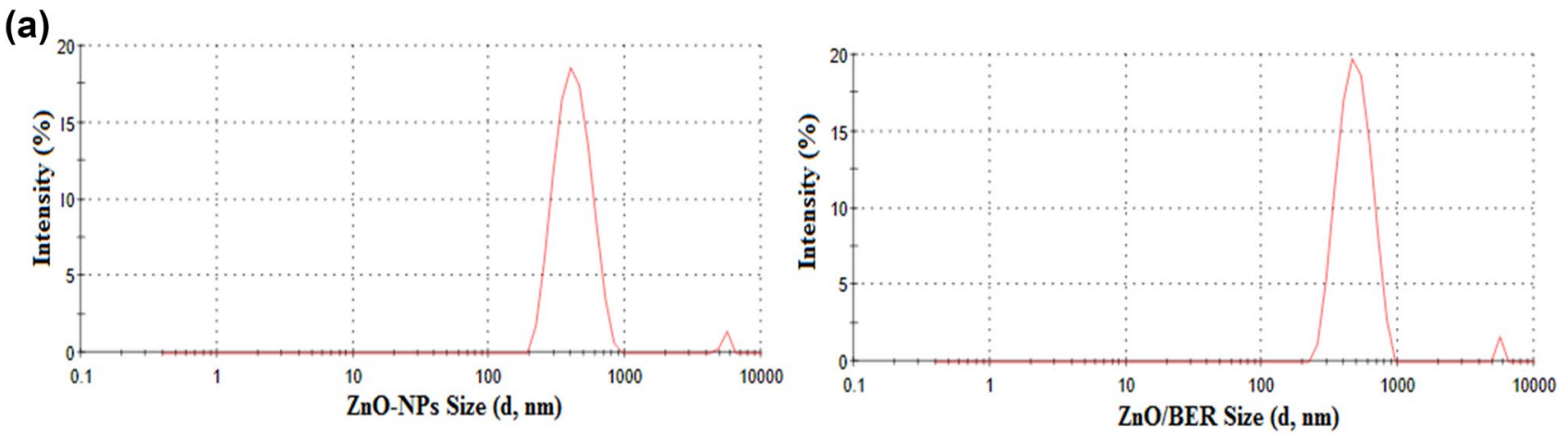

(b)
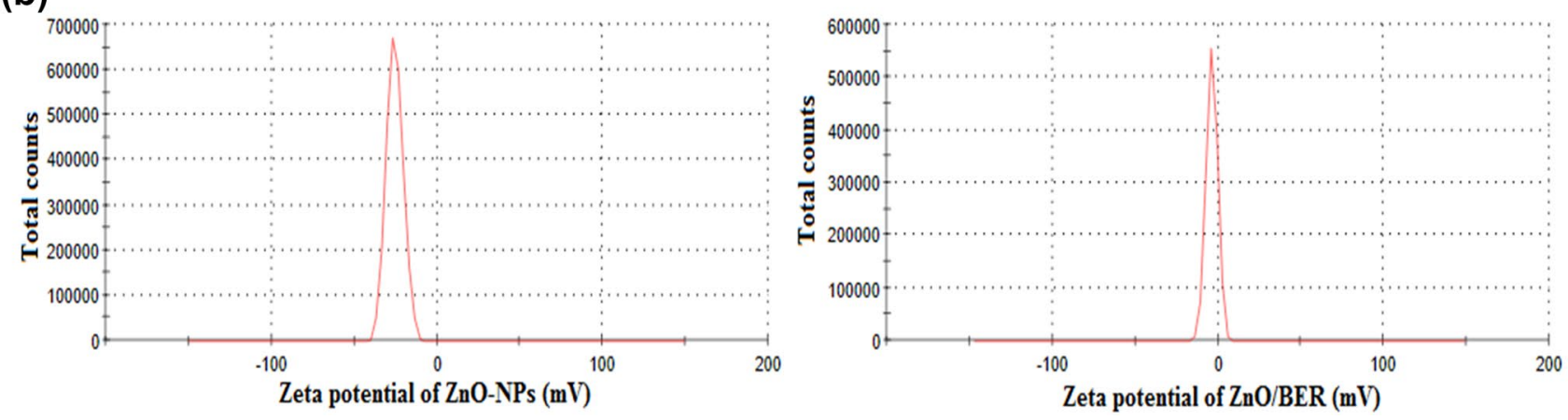

Fig. 2 a Hydrodynamic size $(\mathrm{nm})$ of ZnO-NPs $(448 \mathrm{~nm})$ and $\mathrm{ZnO} / \mathrm{BER}-\mathrm{NPs}(583 \mathrm{~nm})$ suspensions. b Zeta potential in (mv) of ZnO-NPs $(-25.5 \mathrm{mv})$ andZnO/BER $(-3.71 \mathrm{mv})$

cationic BER molecules affects the polydispersity index and increases the aggregation of $\mathrm{ZnO} / \mathrm{BER}$ complex due to the low surface potential of the complex. Hydrogen bonding also may play a role in the formation of the $\mathrm{ZnO} / \mathrm{BER}$ complex where one pair of hydrogen-bond interactions occurs by the hydrogen-bond donors acetal-type $-\mathrm{CH}_{2}-$ group of the 1,3-dioxole ring in BER, which is responsible for BER crystal structure with $\mathrm{ZnO}$ (Pingali et al. 2014; Biradha 2003). The hydrogen bond between this $-\mathrm{CH}_{2}-$ group and the oxygen of $\mathrm{ZnO}$ or dissociated hydroxyl -OH groups could be formed on the surface of $\mathrm{ZnO}-\mathrm{NPs}$, which reduced the intense sharp peak of ZnO-NPs emission spectra at $378 \mathrm{~nm}$ (Fig. 1d). Another possibility of hydrogen bond is between the methoxy $\mathrm{O}$ atom of $\mathrm{BER}$ and $\mathrm{ZnO}$ in which the $\mathrm{Zn}$ atom is coordinately bonded to both methoxy $\mathrm{O}$ atom as shown in Fig. 4b.Additionally, the XRD pattern (Fig. 4b) of the prepared $\mathrm{ZnO} / \mathrm{BER}$ complex shows the presence of less intense diffraction peaks of BER that also indicates the presence of amorphous or semi-crystalline form of BER on the surface of $\mathrm{ZnO}-\mathrm{NPs}$.

\section{The molecular docking study.}

In silico analyses of the tested compounds proved that BER binds with spike protein through BER $O$ atom that interacts with $\mathrm{N}$-atom of Gln1036 (central helix region). BERalso interacts with PLpro and spike protein RBD through hydrophobic interaction (Table 3 and Fig. 5). Whereas, ZnO-NPs bind through an $\mathrm{O}$ atom with spike protein active site (Asp 775 and Thr 778) and spike protein RBD through Tyr 183 and Val 506. Finally, ZnO/BER complex binds with PLpro through $\mathrm{O}$ with O-atom in Asp 77 and Glu 78. Furthermore, it binds with the spike protein through its $\mathrm{O}$ atom with O-atom of Ile666 and Pro862 and binds to the spike protein RBD through the hydrophobic interaction. Additionally, Table 3 shows that $\mathrm{ZnO}$ /BER complex had the lowest estimated $\mathrm{K}_{\mathrm{i}}$ of the three examined proteins and had the highest stability as it showed the lowest binding energy value.

\section{Antiviral effect of $\mathrm{ZnO/BER} \mathrm{complex}$}

Table 1 shows that all the tested compounds had inhibitory activities towards PLpro and increased formation of the RBD spike protein complex. The results indicated that the $\mathrm{ZnO} / \mathrm{BER}$ complex inhibits the spike protein in a non-competitive manner. Furthermore, they had the ability to bind to ACE2 protein (spike protein $\mathrm{RBD}$ ). In particular, the $\mathrm{ZnO} /$ BER complex was the most potent inhibitor towards PLpro followed by BER, ZnO-NPs, and finally HCQ (Table 1). Furthermore, the $\mathrm{ZnO} / \mathrm{BER}$ complex showed the highest inhibitory action towards RBD spike protein followed by HCQ, ZnO-NPs, and finally BER (Table 1). 
(a)

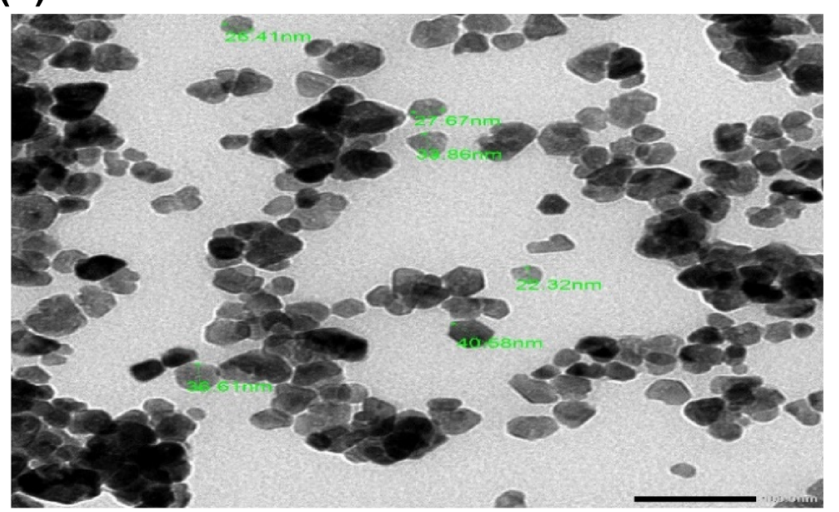

(c)

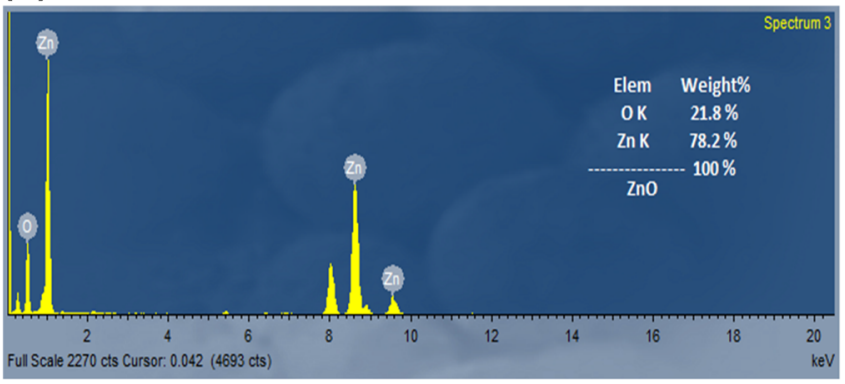

(b)

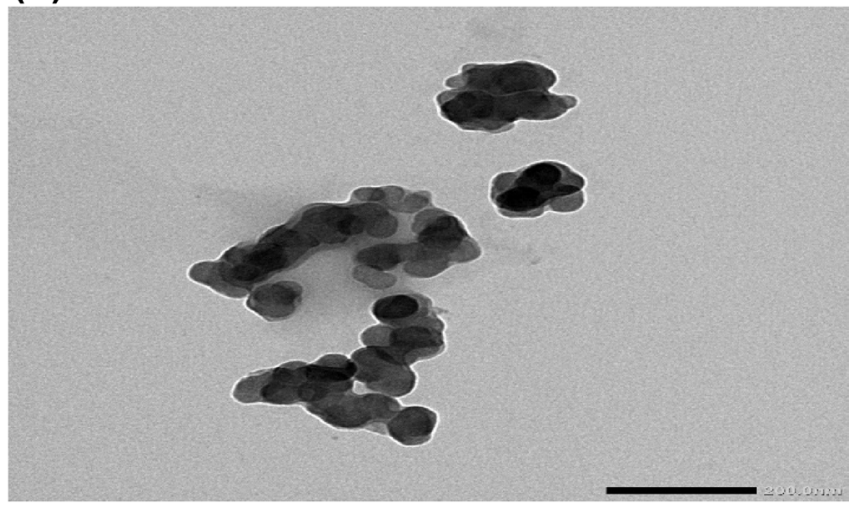

(d)

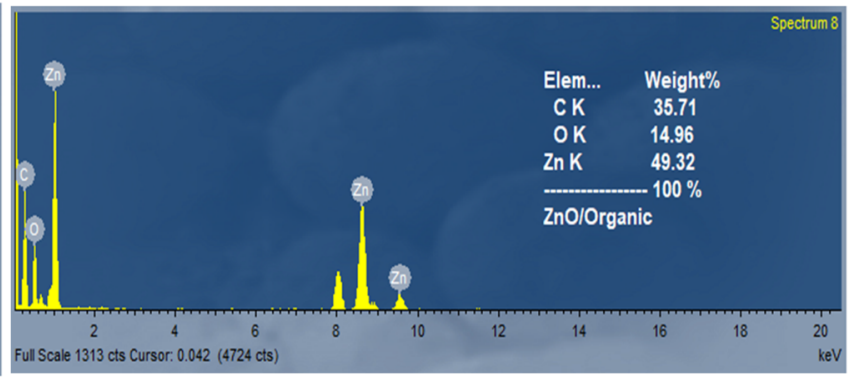

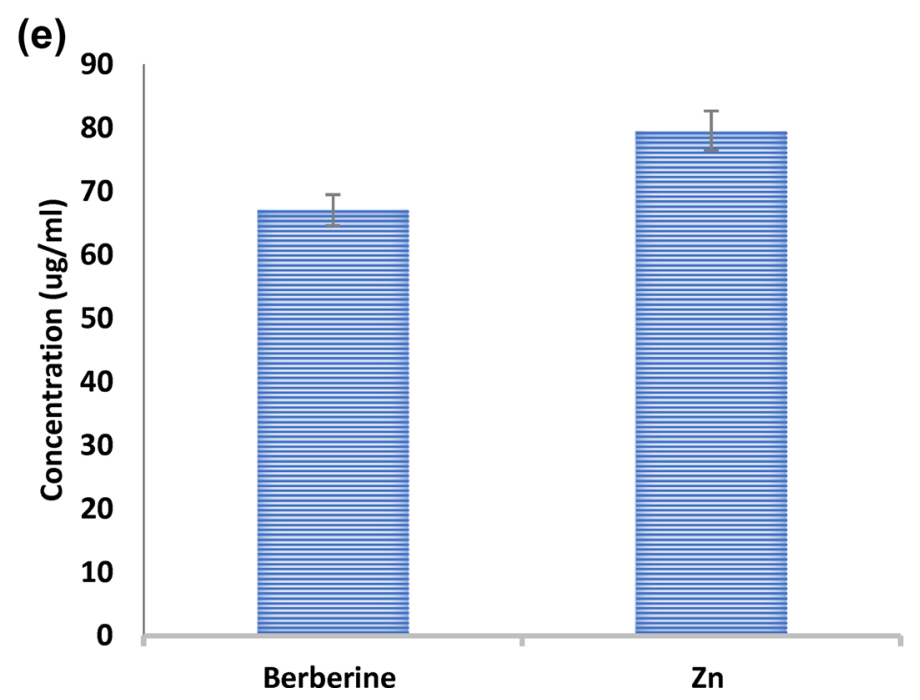

Fig. 3 TEM images of ZnO-NPs a and ZnO/BER-NPs b, Energy Dispersive X-ray analysis (EDX) c, d of ZnO-NPs and ZnO/BER, respectively. e Quantitative determination of both the BER and elemental $\mathrm{Zn}$ content in $\mathrm{ZnO} / \mathrm{BER}$ complex using high-performance liquid chromatography

Te current findings revealed that all the tested compounds act as anti-SARS-CoV2 as all tested compounds decreased the plaque formation $\%$ (Table 4). Remarkably, the best compound used was the $\mathrm{ZnO}$ /BER complex followed by BER, HCQ, and finally ZnO-NPs. In addition, all the tested compounds exhibited a potent antiviral effect as the $\mathrm{EC}_{50}$ (effective antiviral concentration 50) of any of the tested compounds was lower than $\mathrm{IC}_{50}$ (Vero E6 inhibitory concentration 50).

Table 2 demonstrates one of our nos results that the $\mathrm{ZnO}$ NPs, BER and ZnO/BER complex inhibited ORF, E- and RdRp- gene expression. Interestingly, the inhibition pattern was concentration dependent. Consequently, these results are consistent with the inhibition levels of E-protein and spike protein considering that the $\mathrm{ZnO} / \mathrm{BER}$ complex had 

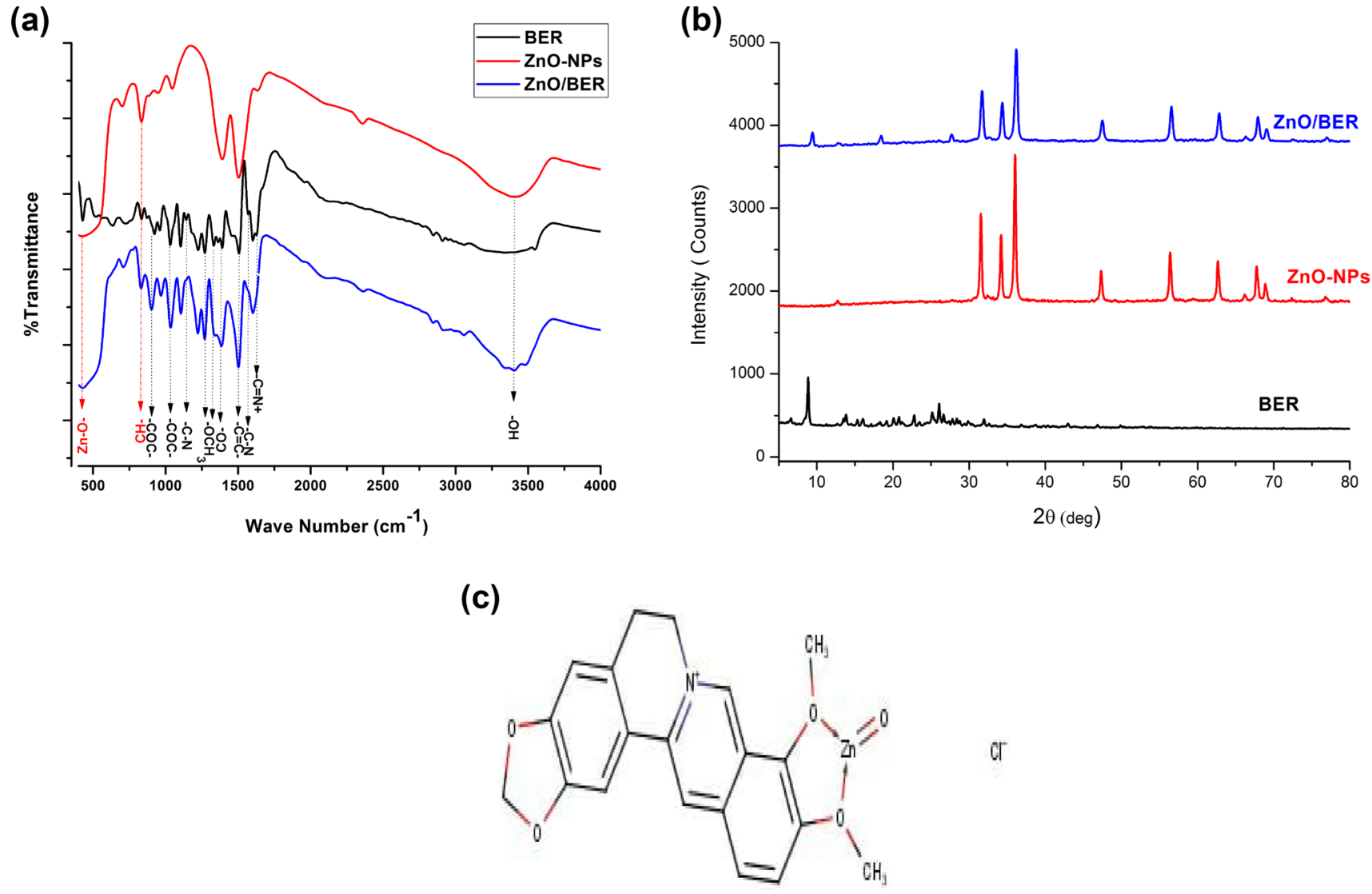

Fig. 4 FT-IR spectral analysis a, X-ray diffraction $\mathbf{b}$ of the ZnO-NPs, BER and ZnO/BER complex and $\mathbf{c}$ theproposed structure of the ZnO/BER complex

Table 3 Docking results of the tested compounds with papainlikeproteinase, spike protein and spike protein receptor-binding domain

\begin{tabular}{|c|c|c|c|}
\hline Parameters & BER & ZnO-NPs & $\mathrm{ZnO} / \mathrm{BER}$ \\
\hline $\mathrm{pH}$ & 2.73 & 6.75 & 3.5 \\
\hline \multicolumn{4}{|c|}{ Papain-likeproteinase } \\
\hline Hydrogen bond & No hydrogen bond & No hydrogen bond & $\begin{array}{l}\text { LIG } 1 \text { O Asp77.A O } \\
\text { LIG } 1 \text { O Glu78.A O }\end{array}$ \\
\hline Binding energy & -8.64 & -2.77 & -10.48 \\
\hline $\begin{array}{l}\text { Estimated } \mathrm{K}_{\mathrm{i}} \\
\text { Spike protein }\end{array}$ & $464.26 \mathrm{nM}$ & $9.28 \mathrm{mM}$ & $11.38 \mathrm{nM}$ \\
\hline Hydrogen bond & Gln1036. BN-LIG O & $\begin{array}{l}\text { LIG1O-Asp775.C OD1 } \\
\text { LIG1O-Thr778.C-OG1 }\end{array}$ & $\begin{array}{l}\text { LIG } 1 \text { O Ile666.A O } \\
\text { LIG } 1 \text { O Pro862.B O } \\
\text { Hydrophobic bonds }\end{array}$ \\
\hline Binding energy & -7.76 & -2.74 & -10.61 \\
\hline Estimated $\mathrm{K}_{\mathrm{i}}$ & $2.05 \mu \mathrm{M}$ & $9880 \mu \mathrm{M}$ & $16.64 \mathrm{nM}$ \\
\hline \multicolumn{4}{|c|}{ Spike protein receptor-binding domain } \\
\hline Hydrogen bond & No hydrogen bond & $\begin{array}{l}\text { LIGO-Tyr183.A OH } \\
\text { LIGO-Val506.A O }\end{array}$ & $\begin{array}{l}\text { LIG Zn-Glu402 A OH } \\
\text { LIG Zn-His378 A NH2 } \\
\text { No hydrogen bond }\end{array}$ \\
\hline Binding energy & -8.51 & -2.31 & -10.77 \\
\hline Estimated $\mathrm{K}_{\mathrm{i}}$ & $0.58097 \mu \mathrm{M}$ & $20,180 \mu \mathrm{M}$ & $12.85 \mathrm{nM}$ \\
\hline
\end{tabular}



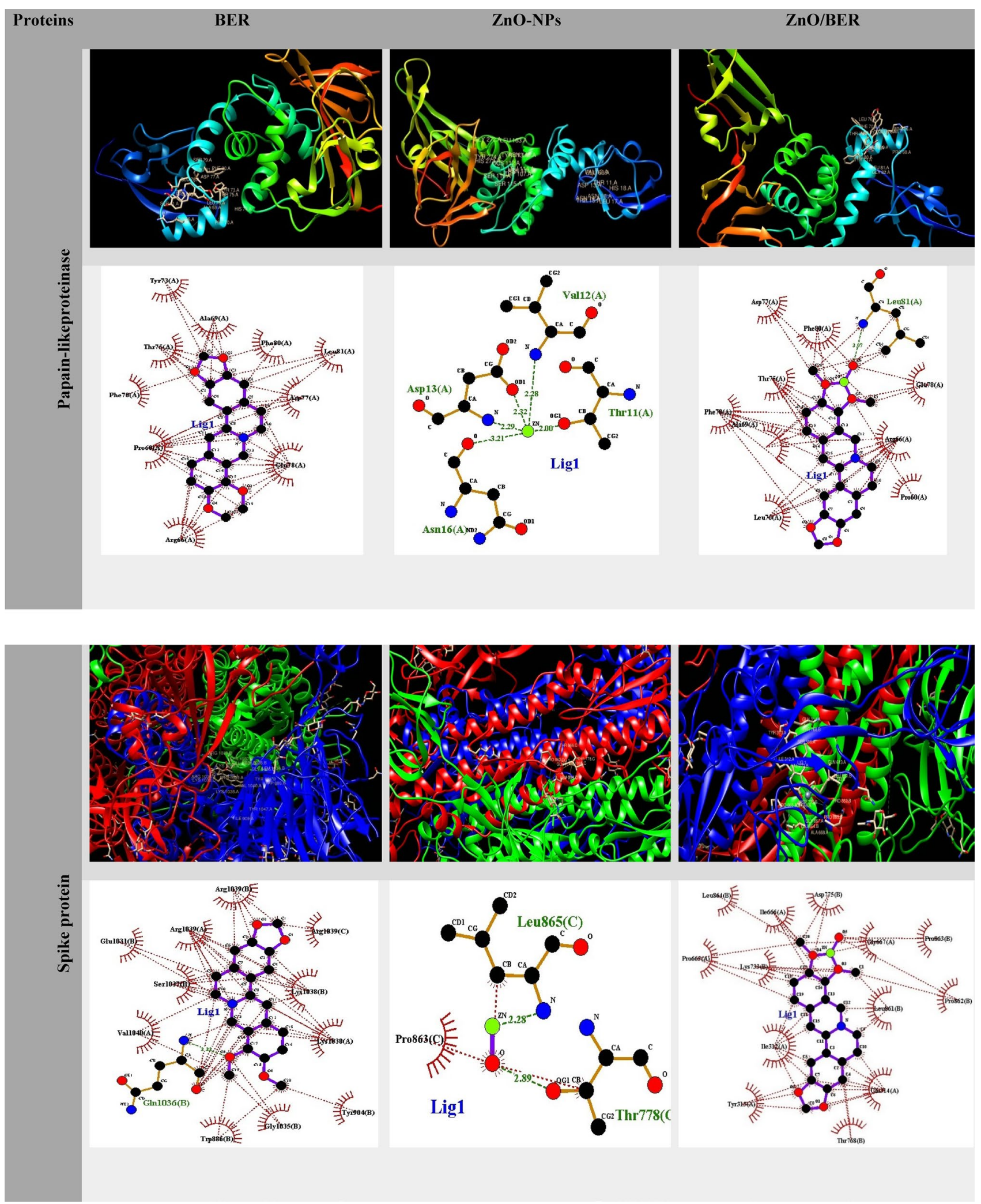

Fig. 5 Molecular docking and LigPlus analysis illustrating the interaction betweenZnO-NPs, BER and ZnO/BER-NPs and the studied proteins (papain-like proteinase, spike protein and spike protein receptor-binding domain) 


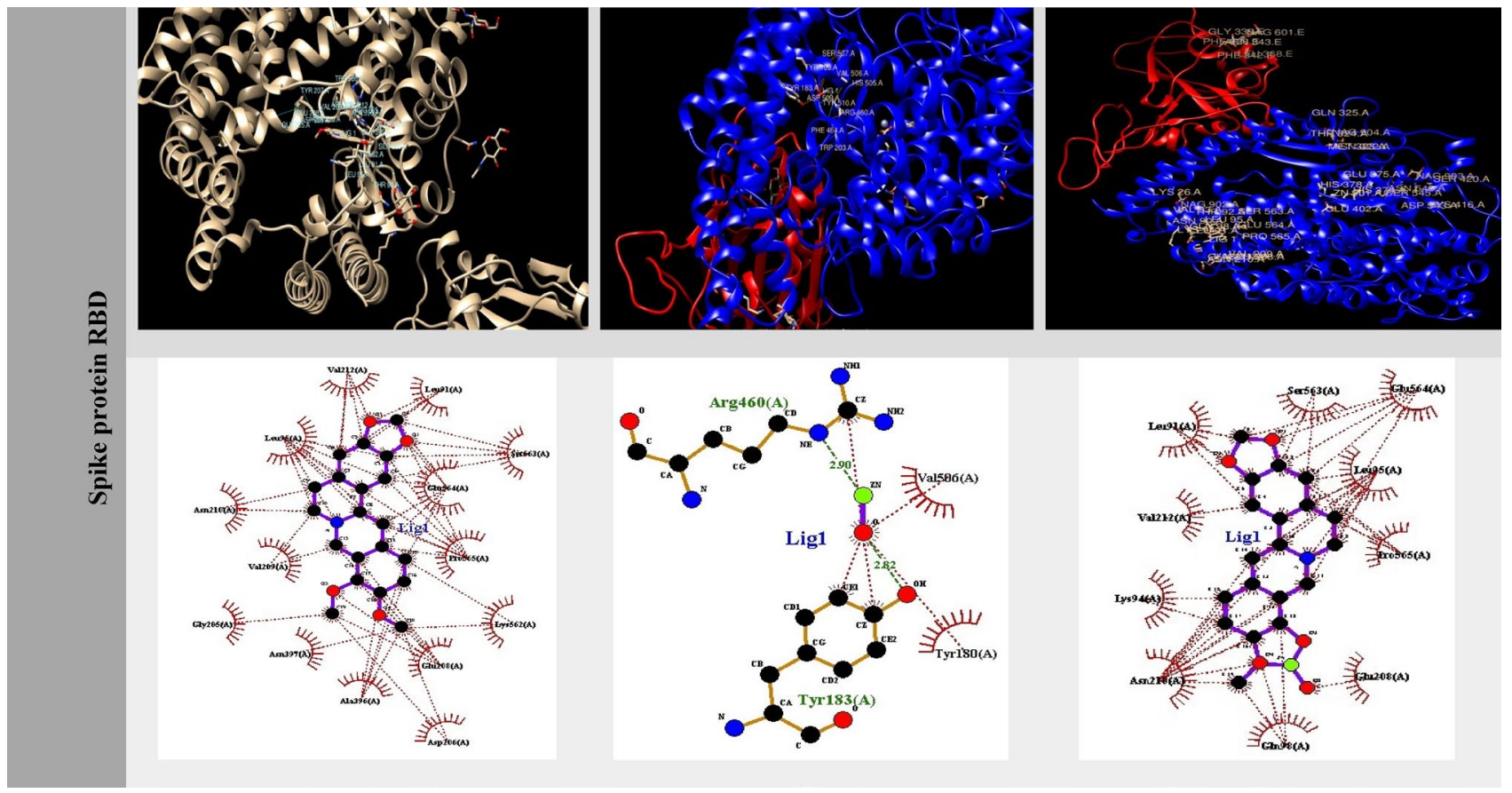

Fig. 5 (continued)

Table 4 Antiviral Activity of the tested compounds using in vitro Vero E6 toxicity and plaque reduction assay against SARS-CoV2

\begin{tabular}{lccccc}
\hline Tested compounds & Vero E6 IC50 $(\mu \mathrm{g} / \mathrm{ml})$ & Vero E6 reduction $(\%)$ & Dosage $(\mu \mathrm{g} / \mathrm{ml})$ & EC50 $(\mu \mathrm{g} / \mathrm{ml})$ & EC50/IC50\% \\
\hline ZnO-NPs & $4.55 \pm 0.03$ & $76.00 \pm 1.5$ & $2.20 \pm 0.002$ & $1.42 \pm 0.002$ & $31.3 \pm 0.7$ \\
BER & $50.73 \pm 0.50$ & $80.00 \pm 1.7$ & $37.04 \pm 0.300$ & $16.70 \pm 0.010$ & $32.9 \pm 0.4$ \\
ZnO/BER & $1.76 \pm 0.002$ & $81.25 \pm 1.2$ & $1.64 \pm 0.01$ & $0.333 \pm 0.003$ & $18.9 \pm 1.2$ \\
HCQ & $1.4 \pm 0.20$ & $76.00 \pm 1.8$ & $.10 \pm 0.050$ & $0.39 \pm 0.009$ & $27.5 \pm 0.9$ \\
\hline
\end{tabular}

the highest protein reduction levels followed by BER and finally $\mathrm{ZnO}-\mathrm{NPs}$ (Table 2). These results indicated that both of the parent compounds as well as $\mathrm{ZnO} / \mathrm{BER}$ complex had an anti-COVID-19 effect through several mechanisms of action where they are involved in cell basicity that subsequently led to the inhibition of the endosomal pathway facilitated by $\mathrm{pH}$-dependent cysteine protease cathepsin L (Xia et al. 2020). They prevent the virus entry by interacting with ACE2 (spike protein RBD) on the cell surface and noncompetitively inhibited spike protein. $\mathrm{ZnO} / \mathrm{BER}$ complex binds by several hydrophobic interactions through Leu 91, Lys 94, Leu 95, Gln 98, Glu 208, Asn 210, Val 212, Ser 563, Glu 564 and Pro 565 that alters the ACE2 active site specificity to substrate (Bhuyan and Mugesh 2012). Furthermore, it binds to the spike protein through hydrogen bonds with Ile 666 and Pro 862 and several hydrophobic interactions with amino acids in A and B chains [Leu 864 (B), Asp 775 (B), Gly 667 (A), Pro 863 (B), Lys 733 (B), Ile 312 (A), Gln 314 (A), Thr 768 (B) and Tyr 313 (A), Pro 665(A), Leu 861(B)].
Since these hydrophobic interactions occurred in the region of the binding site, therefore they alter the protein affinity and substrate specificity (Chandel et al. 2020). These results indicated that the $\mathrm{ZnO} / \mathrm{BER}$ complex is a non-competitive inhibitor that reversibly binds to the enzyme-substrate complex, yielding an inactive ESI complex (Palmer and Bonner 2007).Upon infection, the $\mathrm{ZnO} / \mathrm{BER}$ complex inhibited viral replication by inhibiting PLpro activity and downregulating the expression of RdRp which consequently downregulated the viral structural protein (E-protein and spike protein).

In agreement with our results which indicates the inhibitory activity of the tested compounds towards PLpro, the pervious study showed that the N-terminal of PLprois ubiquitin like domine 2 (UL2) (amino acids 75-88) which is linked to the catalytic site. UL2 mediates a hydrophobic interaction with catalytic site, and thus any change in this region could influence substrate specificity. This inhibition might block the catalytic activity of PLpro towards ubiquitin-like interferon-stimulating 15 protein gene. Therefore, 
Table 5 Antioxidant and cytotoxic effects of the tested compounds

\begin{tabular}{lccc}
\hline & RBC & PBMC & Antioxidants \\
& IC50 $(\mu \mathrm{g} / \mathrm{ml})$ & & \\
\hline ZnO-NPs & $2140.41 \pm 5.9$ & $592 \pm 11.2$ & $2439.02 \pm 12.3$ \\
BER & $1349 \pm 10.3$ & $22.2 \pm 0.9$ & $121.36 \pm 8.7$ \\
ZnO/BER & $178.67 \pm 1.1$ & $6.2 \pm 0.4$ & $160.09 \pm 2.9$ \\
HCQ & $52 \pm 0.9$ & $3.2 \pm 0.3$ & $362.7 \pm 6.7$ \\
\hline
\end{tabular}

antiviral interferon pathway will normally stimulated, and viral replication will be reduce in the infected cells (Shin et al. 2020).

\section{In vitro biological activities of the $\mathrm{ZnO} / \mathrm{BER}$ complex}

\section{Cytotoxicity and antioxidants properties}

According to the routine drug evaluation process, drug toxicity was assessed in vitro on WBC and RBCs (Deore et al. 2019). Moreover, several studies have shown that compounds with antioxidants properties can act as antiCOVID-19 and increase drug efficacy toward the inhibition of the cytokines storm. COVID-19 was found to induce oxidative stress that led to organ failure, and consequently

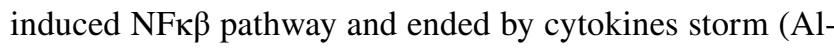
Taie and Victoria 2020; Soto et al. 2020). Our results in Table 5 showed that $\mathrm{ZnO}-\mathrm{NPs}$ was the safest compound towards RBCs and PBMCs where it showed the highest $\mathrm{IC}_{50}$ followed by BER, ZnO/BER complex and finally HCQ. In addition, the $\mathrm{ZnO} / \mathrm{BER}$ complex presented the highest

Table 6 Antimicrobial activity using agar well diffusion and turbidity assays

\begin{tabular}{|c|c|c|c|c|c|c|c|c|}
\hline \multirow{3}{*}{$\begin{array}{l}\text { Concentrations of } \\
\text { the tested com- } \\
\text { pounds }\end{array}$} & \multicolumn{4}{|c|}{ Agar Well Diffusion Assay } & \multicolumn{4}{|l|}{ Turbidity Assay } \\
\hline & \multicolumn{3}{|c|}{ Inhibition zone diameter $(\mathrm{mm})^{\mathrm{a}}$} & \multirow[t]{2}{*}{ MIC $(\mu \mathrm{g} / \mathrm{ml})$} & \multicolumn{3}{|c|}{ Percent of inhibition (\%) } & \multirow[t]{2}{*}{$\operatorname{MIC}(\mu \mathrm{g} / \mathrm{ml})$} \\
\hline & & & & & $100 \%$ & $50 \%$ & $25 \%$ & \\
\hline \multicolumn{9}{|c|}{ Gram negative Bacteria } \\
\hline \multicolumn{9}{|c|}{ klebsila pneumonia ATCC700603 } \\
\hline $\mathrm{ZnO}-\mathrm{NPs}$ & $11 \pm 0.1 \mathrm{E}^{-6}$ & ND & ND & 104 & $65.87 \pm 0.1 \mathrm{E}^{-6}$ & $61.84 \pm 0.1 \mathrm{E}^{-6}$ & $44.13 \pm 0.1 \mathrm{E}^{-6}$ & 26 \\
\hline BER & $20 \pm 0.1 \mathrm{E}^{-6}$ & ND & ND & 1852 & $61.52 \pm 0.1 \mathrm{E}^{-6}$ & $53.21 \pm 0.1 \mathrm{E}^{-6}$ & $40.38 \pm 0.1 \mathrm{E}^{-6}$ & 463 \\
\hline $\mathrm{ZnO} / \mathrm{BER}$ & ND & ND & ND & $\mathrm{ND}$ & $70.22 \pm 0.1 \mathrm{E}^{-6}$ & $67.83 \pm 0.1 \mathrm{E}^{-6}$ & $63.70 \pm 0.1 \mathrm{E}^{-6}$ & 41.6 \\
\hline Positive control & $35 \pm 0.1 \mathrm{E}^{-6}$ & & & & $78.91 \pm 0.1 \mathrm{E}^{-6}$ & & & \\
\hline \multicolumn{9}{|c|}{ Gram positive Bacteria } \\
\hline \multicolumn{9}{|c|}{ Staphylococcus aureus ATCC 25923} \\
\hline ZnO-NPs & $17 \pm 0.1 \mathrm{E}^{-6}$ & ND & ND & 104 & $87.77 \pm 0.1 \mathrm{E}^{-6}$ & $33.24 \pm 0.1 \mathrm{E}^{-6}$ & $8.09 \pm 0.1 \mathrm{E}^{-6}$ & 26 \\
\hline BER & $20 \pm 0.1 \mathrm{E}^{-6}$ & $12 \pm 0.0$ & ND & 926 & $88.30 \pm 0.1 \mathrm{E}^{-6}$ & $67.02 \pm 0.1 \mathrm{E}^{-6}$ & $18.09 \pm 0.1 \mathrm{E}^{-6}$ & 463 \\
\hline $\mathrm{ZnO} / \mathrm{BER}$ & $15 \pm 0.1 \mathrm{E}^{-6}$ & ND & ND & 166.5 & $89.63 \pm 0.1 \mathrm{E}^{-6}$ & $83.24 \pm 0.1 \mathrm{E}^{-6}$ & $79.52 \pm 0.1 \mathrm{E}^{-6}$ & 41.6 \\
\hline Positive control & $25 \pm 0.1 \mathrm{E}^{-6}$ & ND & ND & & $90.43 \pm 0.1 \mathrm{E}^{-6}$ & & & \\
\hline \multicolumn{9}{|c|}{ Streptococcus pyogenes EMCC1772 } \\
\hline $\mathrm{ZnO}-\mathrm{NPs}$ & $12 \pm 0.1 \mathrm{E}^{-6}$ & ND & ND & 104 & $68.31 \pm 0.1 \mathrm{E}^{-6}$ & $50.85 \pm 0.1 \mathrm{E}^{-6}$ & $41.49 \pm 0.1 \mathrm{E}^{-6}$ & 26 \\
\hline BER & $23 \pm 0.1 \mathrm{E}^{-6}$ & $15 \pm 0.0$ & $11 \pm 0.1 \mathrm{E}^{-6}$ & 463 & $64.45 \pm 0.1 \mathrm{E}^{-6}$ & $60.36 \pm 0.1 \mathrm{E}^{-6}$ & $54.97 \pm 0.1 \mathrm{E}^{-6}$ & 463 \\
\hline $\mathrm{ZnO} / \mathrm{BER}$ & $15 \pm 0.1 \mathrm{E}^{-6}$ & ND & ND & 166.5 & $78.69 \pm 0.1 \mathrm{E}^{-6}$ & $78.14 \pm 0.1 \mathrm{E}^{-6}$ & $77.60 \pm 0.1 \mathrm{E}^{-6}$ & 41.6 \\
\hline Positive control & $35 \pm 0.1 \mathrm{E}^{-6}$ & & & & $79.78 \pm 0.1 \mathrm{E}^{-6}$ & & & \\
\hline \multicolumn{9}{|l|}{ Yeast } \\
\hline \multicolumn{9}{|c|}{ Candida albicans EMCC105 } \\
\hline $\mathrm{ZnO}-\mathrm{NPs}$ & $30 \pm 0.1 \mathrm{E}^{-6}$ & $25 \pm 0.1 \mathrm{E}^{-6}$ & $20 \pm 0.1 \mathrm{E}^{-6}$ & 26 & $25.00 \pm 0.1 \mathrm{E}^{-6}$ & $23.44 \pm 0.1 \mathrm{E}^{-6}$ & $20.31 \pm 0.1 \mathrm{E}^{-6}$ & 26 \\
\hline BER & $14 \pm 0.1 \mathrm{E}^{-6}$ & ND & ND & 1852 & $35.94 \pm 0.1 \mathrm{E}^{-6}$ & $32.81 \pm 0.1 \mathrm{E}^{-6}$ & $26.56 \pm 0.1 \mathrm{E}^{-6}$ & 463 \\
\hline $\mathrm{ZnO} / \mathrm{BER}$ & $21 \pm 0.1 \mathrm{E}^{-6}$ & $14 \pm 0.0$ & ND & 83.3 & $40.63 \pm 0.1 \mathrm{E}^{-6}$ & $34.38 \pm 0.1 \mathrm{E}^{-6}$ & $31.25 \pm 0.1 \mathrm{E}^{-6}$ & 41.6 \\
\hline Positive control & $40 \pm 0.1 \mathrm{E}^{-6}$ & & & & $43.75 \pm 0.1 \mathrm{E}^{-6}$ & & & \\
\hline
\end{tabular}

${ }^{\text {a }}$ Diameter includes $5 \mathrm{~mm}$ well diameter

$N D$ Not detected

MIC Minimum inhibition concentration 


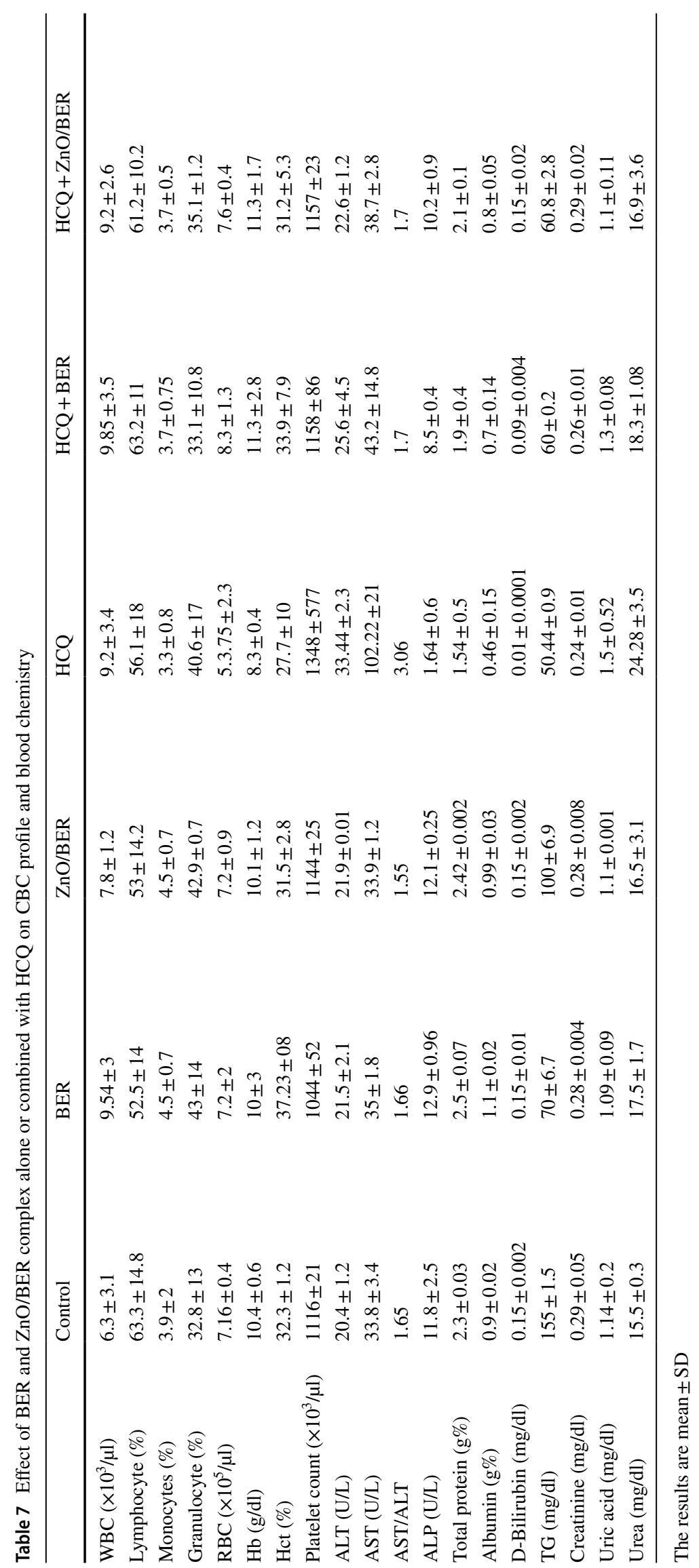




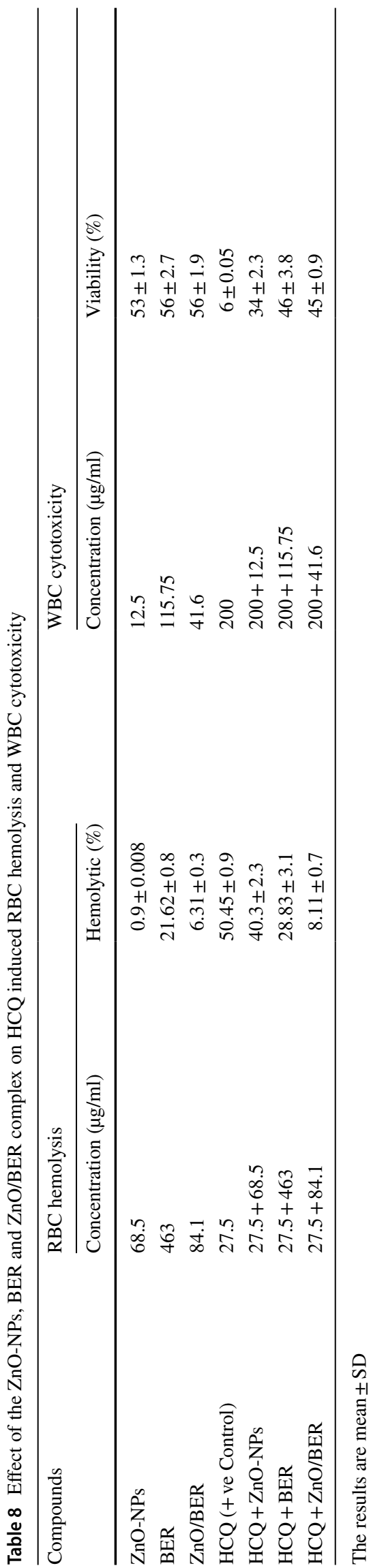

antioxidant capacity followed by BER, HCQ and finally ZnO-NPs.

\section{Antibacterial effect of the ZnO/BER complex}

Studieshave reported that about 3.5\% of COVID-19 patients are co-infected and approximately $14.3 \%$ have a secondary bacterial infection. Moreover, most critically ill patients are known to have bacterial infection which is why most COVID-19 patients received antibiotics (Chen et al. 2020a; Contou et al. 2020; Langford et al. 2020; Sharifipour et al. 2020). In our study, theZnO-NPs, BER and ZnO/BER complex had anti-klebsila pneumonia, Staphylococcus aureus, Streptococcus pyogenes and Candida albicans with the highest antimicrobial activity showed by $\mathrm{ZnO} / \mathrm{BER}$ complex followed by BER then ZnO-NPs (Table 6).

\section{In vitro and in vivo HCQ side effects elimination}

The use of HCQ is controversial (Risch 2020). It depends on pre-clinical data suggesting its anti-viral and anti-inflammatory properties. The clinical trial data demonstrated that HCQ showed no benefit for post-exposure prophylaxis. However, due to its unique pharmacokinetics, HCQ is unlikely to be beneficial in patients with COVID-19 infection. HCQ is taken for 5-10 days to achieve adequate plasma and lung concentrations (Barnabas et al. 2020). As previously mentioned, cardio-ocular toxicity is accounted in patients treated with HCQ. Therefore, the second objective in this study was to estimate the efficacy of the tested compounds against HCQ-induced toxicity in vitro and in vivo. It was found that $\mathrm{ZnO}-\mathrm{NPs}$ decreased the hemolytic activity induced by HCQ by $20.11 \%$, while the BER decreased it by $42.85 \%$ and finally the $\mathrm{ZnO} / \mathrm{BER}$ complex displayed the maximum reduction value of $83.9 \%$ (Table 7). In the case of WBC, ZnO-NPs prevented HCQ cytotoxic effect towards WBC by 4.9 folds, whereas the BER and $\mathrm{ZnO} / \mathrm{BER}$ complex prevented this effect by 6.7 folds approximately, as shown in Table 8.

The in vivo results indicated that the BER and $\mathrm{ZnO} /$ BER complex did not affect normal CBC parameters at $p<0.05$. However, HCQ administration for 14 days significantly decreased the RBC count, $\mathrm{Hb}$ and Hct levels and increased platelet count. Nevertheless, co-administration of HCQ with BER or ZnO/BER complex prevented the HCQ adverse effect, as shown in Table 7. Healthy control mice that received BER or $\mathrm{ZnO} / \mathrm{BER}$ complex showed lower TG levels compared to normal control mice. Furthermore, the group receiving HCQ had significantly lower serum direct bilirubin, ALP, total protein, albumin, T.G. and creatinine associated with elevated AST, ALT, AST/ALT ratio, uric acid and urea levels. Whereas, co-administration with BER moderately prevented the HCQ adverse effect. Interestingly, 
our results exhibited that $\mathrm{ZnO} / \mathrm{BER}$ complex co-administration with HCQ completely prevented the adverse action of HCQ on tissues (Table 7) as all parameters tested were in the normal range for control mice, at $p<0.05$.In agreement with our results, several studies have reported that HCQ induces an increase in fibrinogen causing a decrease in plasmatic and blood viscosity (Ernst et al. 1984). A possible role in the rheological property decreases of RBCs (Bird et al. 1981). Moreover, it causes hepatic failure, toxic epidermal necrolysis and cardiotoxicity (Hashem et al. 2020). BER and $\mathrm{ZnO}-\mathrm{NPs}$ act as antioxidants and have an anti-inflammatory and hepatic support action (El-Zeftawy et al. 2019; Ghaffari et al. 2019) that can eliminate the HCQ adverse effect on these vital tissues.

\section{Conclusion}

The $\mathrm{ZnO} / \mathrm{BER}$ complex was successfully prepared with the freshly prepared facile mixing method of $30 \pm 5 \mathrm{nmZnO}-\mathrm{NPs}$ and BER-HCl. The adsorption of cationic BER molecules on the surface of negatively charged $\mathrm{ZnO}$-NPs was confirmed by the non-covalent bond that played a major role in the reaction of $\mathrm{ZnO}-\mathrm{NPs}$ with $\mathrm{BER}$. $\mathrm{ZnO} / \mathrm{BER}$ complex exhibits potent antioxidant, antiviral and antimicrobial activities and has been found to be effective at lower concentrations than BER or ZnO-NPs alone. The ZnO/BER complex acts as antiCOVID-19 by inhibiting the virus entry through interacting with the ACE2 enzyme on the cell surface and inhibiting the spike protein interaction. Also, the $\mathrm{ZnO} / \mathrm{BER}$ complex inhibits PLpro activity and downregulates the expression of $\mathrm{RdRp}$, which consequently downregulates the viral structural protein and prevents the viral replication. Finally, $\mathrm{ZnO} / \mathrm{BER}$ complex eliminates the toxicity of HCQ administration. The obtained findings proved that $\mathrm{ZnO} / \mathrm{BER}$ complex can offer a promising therapeutic option for managing COVID-19 infection and related bacterial co-infection that occurred in many cases. It can also be used in the therapeutic protocol using HCQ to eliminate related adverse effects and especially in case of patients suffering from autoimmune disorders and treated with HCQ.

Funding The authors did not receive any funding for this research.

Data availability The raw/processed data required to reproduce these findings cannot be shared at this time as the data also form part of an ongoing study.

\section{Declarations}

Conflict of interest All authors (D.A. Ghareeb, S.R. Saleh, M.G. Seadawy, M.S. Nofal, S.A. Abdulmalek, S.F. Hassan, S.M. Khedr, M.G. AbdElwahab, A.A. Sobhy, A.A. Abdel-Hamid, A.M. Yassin, A.A.A.
Elmoneam, A.A. Masoud, M.M.Y. Kaddah, S.A. El-Zahaby, A.M. Almahallawi, A.M. El-Gharbawy, A. Zaki, I.K. Seif, M.Y. Kenawy, M. Amin, K. Amer, M.A. El Demellawy) declare that they have no known competing financial interests or personal relationships that could appear to influence the work reported in this paper.

Ethical approval This article does not contain any studies on human participants performed by any of the authors.

Animal rights The animal experiment design protocol was approved by ethics committee of animal research in (PFIDC), SRTA-City, Institutional Animal Care and Use Committees (IACUC)/ IACUC \# 19-1R01020.

\section{References}

Abd El-Salam M, Mekky H, El-Naggar EMB, Ghareeb D, ElDemellawy M, El-Fiky F (2015) Hepatoprotective properties and biotransformation of berberine and berberrubine by cell suspension cultures of Dodonaea viscosa and Ocimum basilicum. S Afr J Bot 97:191-195

Aditya A, Chattopadhyay S, Gupta N, Alam S, Veedu AP, Pal M, Singh A, Santhiya D, Ansari KM, Ganguli M (2019) ZnO Nanoparticles Modified with an Amphipathic Peptide Show Improved Photoprotection in Skin. ACS Appl Mater Interfaces 11:56-72

Agency EM (2020) COVID-19: chloroquine and lydroxychloroquine only be used in clinical trials or emergency use programmes [Online]. Available: https://www.ema.europa.eu/en/news/covid19-chloroquine-hydroxychloroquine-only-be-used-clinical-trialsemergency-use-programmes. Accessed 1 Apr 2020

Al-Taie A, Victoria A (2020) Supplementary medicines and antioxidants in viral infections: a review of proposed effects for COVID19. Biomed Biotechnol Res J 4:19-24

Barnabas RV, Brown ER, Bershteyn A, Stankiewicz Karita HC, Johnston C, Thorpe LE, Kottkamp A, Neuzil KM, Laufer MK, Deming M, Paasche-Orlow MK, Kissinger PJ, Luk A, Paolino K, Landovitz RJ, Hoffman R, Schaafsma TT, Krows ML, Thomas KK, Morrison S, Haugen HS, Kidoguchi L, Wener M, Greninger AL, Huang M-L, Jerome KR, Wald A, Celum C, Chu HY, Baeten JM (2020) Hydroxychloroquine as postexposure prophylaxis to prevent severe acute respiratory syndrome coronavirus 2 infection. Ann Internal Med.

Bashmakova N, Kutovyy S, Zhurakivsky R, Hovorun D, Yashchuk V (2011) Vibrational spectra of berberine and their interpretation by means of DFT quantum-mechanical calculations. Ukr J Phys 56.

Battu SK, Repka MA, Maddineni S, Chittiboyina AG, Avery MA, Majumdar S (2010) Physicochemical characterization of berberine chloride: a perspective in the development of a solution dosage form for oral delivery. AAPS PharmSciTech 11:1466-1475

Belay A, Kim HK, Hwang Y-H (2017) Spectroscopic study of binding of chlorogenic acid with the surface of $\mathrm{ZnO}$ nanoparticles. Russ J Phys Chem A 91:1781-1790

Bhogale A, Patel N, Mariam J, Dongre PM, Miotello A, Kothari DC (2013) Study of interaction of $\mathrm{ZnO}$ nanoparticles with human serum albumin using fluorescence spectroscopy. AIP Conf Proc 1512:130-131

Bhuyan BJ, Mugesh G (2012) Antioxidant activity of peptide-based angiotensin converting enzyme inhibitors. Org Biomol Chem 10:2237-2247

Biradha K (2003) Crystal engineering: from weak hydrogen bonds to co-ordination bonds. CrystEngComm 5:374-384 
Bird HA, Harkness J, Wright V (1981) Some rheological properties of blood during anti-rheumatoid therapy. Pharmatherapeutica $3: 36-39$

Brand-Williams W, Cuvelier M-E, Berset C (1995) Use of a free radical method to evaluate antioxidant activity. LWT-Food Sci Technol 28:25-30

Caly L, Druce JD, Catton MG, Jans DA, Wagstaff KM (2020) The FDA-approved drug ivermectin inhibits the replication of SARSCoV-2 in vitro. Antiviral Res 178:104787

Chandel V, Sharma PP, Raj S, Choudhari R, Rathi B, Kumar D (2020) Structure-based drug repurposing for targeting Nsp9 replicase and spike proteins of severe acute respiratory syndrome coronavirus 2. J Biomol Struct Dyn: 1-14.

Chen X, Liao B, Cheng L, Peng X, Xu X, Li Y, Hu T, Li J, Zhou X, Ren B (2020a) The microbial coinfection in COVID-19. Appl Microbiol Biotechnol 104:7777-7785

Chen Y, Liu Q, Guo D (2020b) Emerging coronaviruses: genome structure, replication, and pathogenesis. J Med Virol 92:418-423

Contou D, Claudinon A, Pajot O, Micaëlo M, Longuet Flandre P, Dubert M, Cally R, Logre E, Fraissé M, Mentec H, Plantefève $\mathrm{G}$ (2020) Bacterial and viral co-infections in patients with severe SARS-CoV-2 pneumonia admitted to a French ICU. Ann Intensive Care 10:119

Deore A, Dhumane J, Wagh R, Sonawane R (2019) The stages of drug discovery and development process. Asian J Pharm Res Dev $7: 62-67$

Dubey A, Shetty A, Ravi G, Kiritkumar MC, Prabhu P, Hebbar S, ElZahaby SA (2018) Development and investigation of novel solid self-nanoemulsifying system loaded with hydrochlorothiazide for the treatment of hypertension. Int J Pharm Invest 8:83-91

El-Zahaby SA, Aboughaly MH, Abdelbary GA, El-Gazayerly ON (2016) Development of a novel solid self-nano-emulsifying osmotically controlled system of a centrally acting drug: preparation and in-vitro evaluation. Inventi Impact NDDS 2016:35-49

El-Zeftawy M, Ghareeb D, Elbealy ER, Saad R, Mahmoud S, Elguindy N, El-Kott AF, El-Sayed M (2019) Berberine chloride ameliorated $\mathrm{PI} 3 \mathrm{~K} /$ Akt-p/SIRT-1/PTEN signaling pathway in insulin resistance syndrome induced in rats. J Food Biochem 43:e13049

Ernst E, Rose M, Lee R (1984) Modification of transoperative changes in blood fluidity by hydroxychloroquine: a possible explanation for the drug's antithrombotic effect. Pharmatherapeutica 4:48-52

Espitia, P., Otoni, C. \& Soares, N. 2016. Zinc Oxide Nanoparticles for Food Packaging Applications.

Estrada-Urbina J, Cruz-Alonso A, Santander-González M, MéndezAlbores A, Vázquez-Durán A (2018) Nanoscale zinc oxide particles for improving the physiological and sanitary quality of a mexican landrace of red maize. Nanomaterials (Basel), 8 .

Ghaffari H, Tavakoli A, Moradi A, Tabarraei A, Bokharaei-Salim F, Zahmatkeshan M, Farahmand M, Javanmard D, Kiani SJ, Esghaei M, Pirhajati-Mahabadi V, Monavari SH, Ataei-Pirkooh A (2019) Inhibition of H1N1 influenza virus infection by zinc oxide nanoparticles: another emerging application of nanomedicine. $\mathrm{J}$ Biomed Sci 26:70

Ghareeb AE, Moawed FSM, Ghareeb DA, Kandil EI (2018) Potential prophylactic effect of berberine against rat colon carcinoma induce by 1,2-Dimethyl Hydrazine. Asian Pac J Cancer Prev 19:1685-1690

Ghareeb DA, Abd El-Wahab AE, Sarhan EE, Abu-Serie MM, El Demellawy MA (2013) Biological assessment of Berberis vulgaris and its active constituent, berberine: Antibacterial, antifungal and anti-hepatitis C virus (HCV) effect. J Med Plants Res 7:1529-1536

Ghareeb DA, Elwakeel EH, Khalil R, Aziz MS, El Demellawy MA (2016) Investigation of the immunomodulatory effect of Berberis vulgaris on core-pulsed dendritic cell vaccine. BMC Complement Altern Med 16:325
Ghareeb DA, Saleh SR, Nofal MS, Kaddah MM, Hassan SF, Seif IK, El-Zahaby SA, Khedr SM, Kenawy MY, Masoud AA (2021) Potential therapeutic and pharmacological strategies for SARSCoV2. J Pharm Invest, 1-16

Hashem AM, Alghamdi BS, Algaissi AA, Alshehri FS, Bukhari A, Alfaleh MA, Memish ZA (2020) Therapeutic use of chloroquine and hydroxychloroquine in COVID-19 and other viral infections: a narrative review. Travel Med Infect Dis 35:101735

Hussien HM, Abd-Elmegied A, Ghareeb DA, Hafez HS, Ahmed HEA, El-Moneam NA (2018) Neuroprotective effect of berberine against environmental heavy metals-induced neurotoxicity and Alzheimer's-like disease in rats. Food Chem Toxicol 111:432-444

Irimpan L, Nampoori VPN, Radhakrishnan P, Deepthy A, Krishnan B (2007) Size dependent fluorescence spectroscopy of nanocolloids of ZnO. J Appl Phys 102:063524

Jia B, Li Y, Wang D, Duan R (2014) Study on the interaction of $\beta$-cyclodextrin and berberine hydrochloride and its analytical application. PLOS One 9:e95498

Jiang J, Pi J, Cai J (2018) The advancing of zinc oxide nanoparticles for biomedical applications. Bioinorg Chem Appl 2018:1062562

Kadaikunnan S, Rejiniemon TS, Khaled JM, Alharbi NS, Mothana R (2015) In-vitro antibacterial, antifungal, antioxidant and functional properties of Bacillus amyloliquefaciens. Ann Clin Microbiol Antimicrob 14:9

Kathiravan A, Paramaguru G, Renganathan R (2009) Study on the binding of colloidal zinc oxide nanoparticles with bovine serum albumin. J Mol Struct 934:129-137

Kim S, Lee SY, Cho HJ (2018) Berberine and zinc oxide-based nanoparticles for the chemo-photothermal therapy of lung adenocarcinoma. Biochem Biophys Res Commun 501:765-770

Langford BJ, So M, Raybardhan S, Leung V, Westwood D, Macfadden DR, Soucy JR, Daneman N (2020) Bacterial co-infection and secondary infection in patients with COVID-19: a living rapid review and meta-analysis. Clin Microbiol Infect 26:1622-1629

Liu C, Zhou Q, Li Y, Garner LV, Watkins SP, Carter LJ, Smoot J, Gregg AC, Daniels AD, Jervey S, Albaiu D (2020a) Research and development on therapeutic agents and vaccines for COVID-19 and related human coronavirus diseases. ACS Cent Sci 6:315-331

Liu J, Cao R, Xu M, Wang X, Zhang H, Hu H, Li Y, Hu Z, Zhong W, Wang M (2020b) Hydroxychloroquine, a less toxic derivative of chloroquine, is effective in inhibiting SARS-CoV-2 infection in vitro. Cell Discov 6:16

Liu Q, Xie Z, Liu T, Fan J (2018) Determination of berberine hydrochloride using a fluorimetric method with silica nanoparticles as a probe. RSC Adv 8:6075-6082

Mahmoud MA, Ghareeb DA, Sahyoun HA, Elshehawy AA, Elsayed MM (2016) In vivo interrelationship between insulin resistance and interferon gamma production: protective and therapeutic effect of berberine. Evid Based Complement Alternat Med 2016:2039897

Minaiyan M, Ghannadi A, Mahzouni P, Jaffari-Shirazi E (2011) Comparative study of berberis vulgaris fruit extract and berberine chloride effects on acetic acid-induced colitis in rats. Iran J Pharm Res 10:97-104

Nagaraju G, Udayabhanu S, Prashanth SA, Shastri M, Yathish KV, Anupama C, Rangappa D (2017) Electrochemical heavy metal detection, photocatalytic, photoluminescence, biodiesel production and antibacterial activities of $\mathrm{Ag}-\mathrm{ZnO}$ nanomaterial. Mater Res Bull 94:54-63

Palmer T, Bonner PL (2007) Enzymes biochemistry, biotechnology, clinical chemistry, Woodhead Publishing.

Pingali S, Donahue J, Payton-Stewart F (2014) Weak C-H $\cdots X(X=O$, $\mathrm{N})$ hydrogen bonds in the crystal structure of dihydroberberine. Acta crystallographica Section c Struct Chem 70:388-391

Raafat KM, El-Zahaby SA (2020) Niosomes of active Fumaria officinalis phytochemicals: antidiabetic, antineuropathic, 
anti-inflammatory, and possible mechanisms of action. Chin Med $15: 1-22$

Repetto G, Del Peso A, Zurita JL (2008) Neutral red uptake assay for the estimation of cell viability/cytotoxicity. Nat Protoc 3:1125-1131

Risch HA (2020) Early outpatient treatment of symptomatic, high-risk COVID-19 patients that should be ramped up immediately as key to the pandemic crisis. Am J Epidemiol 189:1218-1226

Saleh SR, Attia R, Ghareeb DA (2018) The ameliorating effect of berberine-rich fraction against gossypol-induced testicular inflammation and oxidative stress. Oxid Med Cell Longev 2018:1056173

Shang J, Wan Y, Liu C, Yount B, Gully K, Yang Y, Auerbach A, Peng G, Baric R, Li F (2020) Structure of mouse coronavirus spike protein complexed with receptor reveals mechanism for viral entry. PLoS Pathog 16:e1008392-e1008392

Sharifipour E, Shams S, Esmkhani M, Khodadadi J, Fotouhi-Ardakani R, Koohpaei A, Doosti Z, Ej Golzari S (2020) Evaluation of bacterial co-infections of the respiratory tract in COVID-19 patients admitted to ICU. BMC Infect Dis 20:646

Shin D, Mukherjee R, Grewe D, Bojkova D, Baek K, Bhattacharya A, Schulz L, Widera M, Mehdipour AR, Tascher G, Geurink PP, Wilhelm A, Der Heden V, Van Noort GJ, Ovaa H, Müller S, Knobeloch K-P, Rajalingam K, Schulman BA, Cinatl J, Hummer G, Ciesek S, Dikic I (2020) Papain-like protease regulates SARSCoV-2 viral spread and innate immunity. Nature 587:657-662

Soto ME, Guarner-Lans V, Soria-Castro E, Manzano Pech L, PérezTorres I (2020) Is antioxidant therapy a useful complementary measure for covid-19 treatment? an algorithm for its application. Medicina 56:386

Soudi SA, Nounou MI, Sheweita SA, Ghareeb DA, Younis LK, ElKhordagui LK (2019) Protective effect of surface-modified berberine nanoparticles against LPS-induced neurodegenerative changes: a preclinical study. Drug Deliv Transl Res 9:906-919

Strekal N, Motevich I, Nowicky J, Maskevich S (2007) IR absorption and surface-enhanced Raman spectra of the isoquinoline alkaloid berberine. J Appl Spectrosc 74:31-37

Taefehshokr N, Taefehshokr S, Hemmat N, Heit B (2020) Covid19: perspectives on innate immune evasion. Front Immunol 11:580641-580641
Tai W, He L, Zhang X, Pu J, Voronin D, Jiang S, Zhou Y, Du L (2020) Characterization of the receptor-binding domain (RBD) of 2019 novel coronavirus: implication for development of RBD protein as a viral attachment inhibitor and vaccine. Cell Mol Immunol 17:613-620

Tang T, Bidon M, Jaimes JA, Whittaker GR, Daniel S (2020) Coronavirus membrane fusion mechanism offers a potential target for antiviral development. Antiviral Res 178:104792

Wang M, Cao R, Zhang L, Yang X, Liu J, Xu M, Shi Z, Hu Z, Zhong W, Xiao G (2020) Remdesivir and chloroquine effectively inhibit the recently emerged novel coronavirus (2019-nCoV) in vitro. Cell Res 30:269-271

Wen MM, Abdelwahab IA, Aly RG, El-Zahaby SA (2021) Nanophytogel against multi-drug resistant Pseudomonas aeruginosa burn wound infection. Drug Delivery 28:463-477

Who. 2021. Coronavirus (COVID-19) Update: FDA Authorizes Drug Combination for Treatment of COVID-19 [Online]. Available: https://www.fda.gov/news-events/press-announcements/coron avirus-covid-19-update-fda-authorizes-drug-combination-treat ment-covid-19. Accessed 12 March 2021.

Xia S, Liu M, Wang C, Xu W, Lan Q, Feng S, Qi F, Bao L, Du L, Liu S, Qin C, Sun F, Shi Z, Zhu Y, Jiang S, Lu L (2020) Inhibition of SARS-CoV-2 (previously 2019-nCoV) infection by a highly potent pan-coronavirus fusion inhibitor targeting its spike protein that harbors a high capacity to mediate membrane fusion. Cell Res 30:343-355

Zhou Y, Hou Y, Shen J, Huang Y, Martin W, Cheng F (2020) Networkbased drug repurposing for novel coronavirus 2019-nCoV/SARSCoV-2. Cell Discovery 6:14

Zou L, Dai L, Zhang X, Zhang Z, Zhang Z (2020) Hydroxychloroquine and chloroquine: a potential and controversial treatment for COVID-19. Arch Pharmacal Res 43:765-772

Publisher's Note Springer Nature remains neutral with regard to jurisdictional claims in published maps and institutional affiliations.

\section{Authors and Affiliations}

\section{Doaa A. Ghareeb ${ }^{1,2,3} \cdot$ Samar R. Saleh ${ }^{1,2,3} \cdot$ Mohamed G. Seadawy $^{4}$. Mohammed S. Nofal ${ }^{1}$. Shaymaa A. Abdulmalek ${ }^{1,2,3}$. Salma F. Hassan ${ }^{1}$. Shaimaa M. Khedr ${ }^{1}$ - Miral G. AbdElwahab ${ }^{1}$. Ahmed A. Sobhy ${ }^{1,2,5}$. Ali saber Ali Abdel-Hamid ${ }^{1}$. Abdelrahman Mohamed Yassin ${ }^{1}$. Alshimaa A. Abd Elmoneam ${ }^{2,3}$. Aliaa A. Masoud ${ }^{2,3}$. Mohamed M. Y. Kaddah ${ }^{1}$. Sally A. El-Zahaby ${ }^{6}$ - Abdulaziz Mohsen Al-mahallawi ${ }^{7,8}$. Alaa M. El-Gharbawy ${ }^{1}$. Ahmed Zaki ${ }^{1} \cdot$ Inas K. Seif ${ }^{1,2,3} \cdot$ Marwa Y. Kenawy ${ }^{2,3,9} \cdot$ Magdy Amin $^{10} \cdot$ Khaled Amer $^{11} \cdot$ Maha Adel El Demellawy $^{1,12}$}

1 Center of Excellence for Drug Preclinical Studies (CE-DPS), Pharmaceutical and Fermentation Industry Development Center, City of Scientific Research \& Technological Applications, New Borg El Arab, Alexandria, Egypt

2 Bio-Screening and Preclinical Trial Lab, Biochemistry Department, Faculty of Science, Alexandria University, Alexandria, Egypt

3 Biochemistry Department, Faculty of Science, Alexandria University, Alexandria, Egypt

4 Chemical Warfare Department, MCL Almaza, Cairo, Egypt

5 Clinical Pharmacy Program, Faculty of Pharmacy, Alexandria University, Alexandria, Egypt
6 Department of Pharmaceutics and Pharmaceutical Technology, Faculty of Pharmacy, Pharos University in Alexandria, Alexandria, Egypt

7 Department of Pharmaceutics and Industrial Pharmacy, Faculty of Pharmacy, Cairo University, Cairo, Egypt

8 School of Life and Medical Sciences, University of Hertfordshire Hosted by Global Academic Foundation, New Administrative Capital, Cairo, Egypt

9 Fabrication Technology Research Department, Advanced Technology and New Materials Research Institute (ATNMRI), City of Scientific Research and Technological Applications (SRTA-City), New Borg El-Arab City, Alexandria 21934, Egypt 
10 Military Medical Services, Cairo, Egypt

11 Egypt Center for Research and Regenerative Medicine, Cairo, Egypt
12 Medical Biotechnology Department, Genetic Engineering and Biotechnology Research Institute, City of Scientific Research \& Technological Applications, New Borg El Arab, Alexandria, Egypt 